\title{
Conditions of Employment and Small Business: Coverage, Compliance and Exemptions
}

\author{
Shane Godfrey \\ Johann Maree \\ Jan Theron \\ Labour and Enterprise Project \\ Sociology Department \\ Institute of Development and Labour Law \\ University of Cape Town \\ godfrey@humanities.uct.ac.za
}




\section{Acknowledgement}

This Working Paper is one in a series emanating from the SMME project, within the Employment Promotion Programme, which is aimed at Understanding the Regulatory Environment for Small Business in South Africa. The DPRU are the Programme Managers of this DFID funded project whose goal is to promote an enabling environment for employment creation in South Africa, and to contribute to the Government's goal of reducing unemployment.

Development Policy Research Unit

Tel: +2721650 5705

Fax: +27 216505711
Information about our Working Papers and other published titles are available on our website at: http://www.commerce.uct.ac.za/dpru/ 


\section{Glossary}

\begin{tabular}{|c|c|c|}
\hline BCEA & - & Basic Conditions of Employment Act \\
\hline LRA & - & Labour Relations Act \\
\hline LFS & - & Labour Force Survey \\
\hline DoL & - & Department of Labour \\
\hline NEDLAC & - & National Economic Development and Labour Council \\
\hline CCMA & - & Commission for Conciliation Mediation and Arbitration \\
\hline COFESA & - & Confederation of Employers of South Africa \\
\hline ECC & - & Employment Conditions Commission \\
\hline SARS & - & South African Revenue Service \\
\hline UIF & - & Unemployment Insurance Fund \\
\hline Tokiso & - & $\begin{array}{l}\text { Tokiso means "fix it up" in Sotho. They provide independent } \\
\text { dispute settlement services to the private and public sectors. }\end{array}$ \\
\hline
\end{tabular}




\section{Table of Contents}

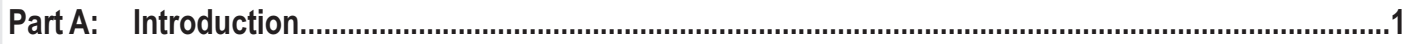

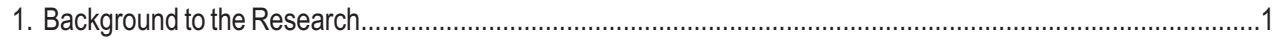

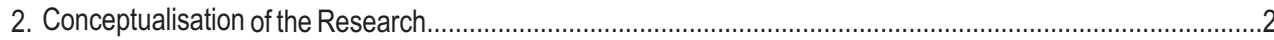

2.1 Coverage and Representivity....................................................................................2

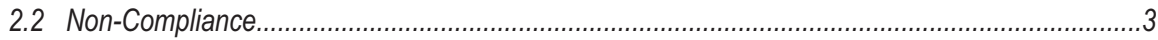

2.3 Enforcement

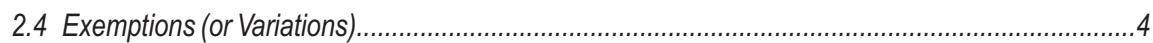

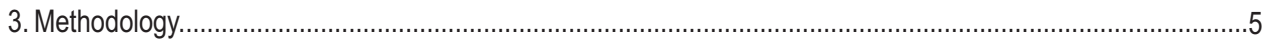

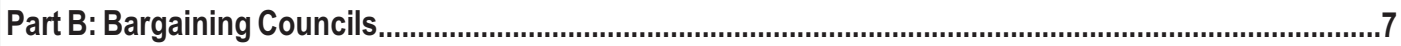

1. The Labour Relations Act (LRA) ......................................................................................................

1.1 Representivity: Registration of Bargaining Councils..............................................................

1.2 Representivity: Extension of Bargaining Council Agreements....................................................

1.3 Representation of Small Businesses.....................................................................................11

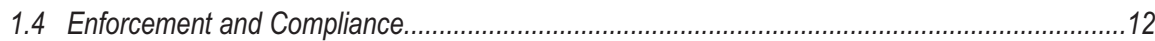

1.5 Non-Standard Employment and Non-Registration..............................................................13

1.6 Dispute Resolution.................................................................................................14

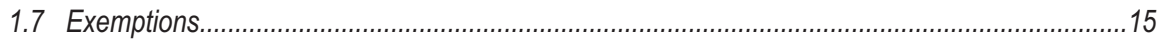

1.8 Data Collected by the Department of Labour............................................................................16

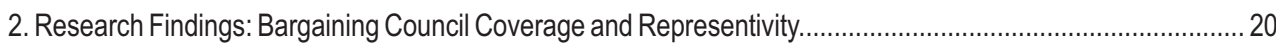

2.1 Bargaining Council Coverage............................................................................................2

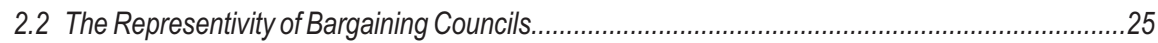

2.3 Bargaining Council Representivity and Size of Firms............................................................

2.4 DoL Data on Small Business Representation on Councils..........................................................35

2.5 Qualitative Interviews Regarding Small Business Representation...........................................40

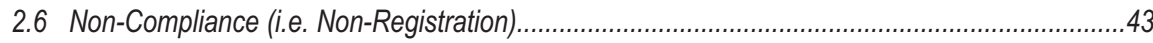


2.7 Benefit Funds, Services and Wage Levels.

3. Research Findings: Enforcement and Compliance.

3.1 Bargaining Council Agents (Inspectors) and Inspections.

3.2 Compliance Orders. . .59

4. Research Findings: Exemptions from Bargaining Council Agreements. .65

4.1 Structures for Considering Exemptions...... .65

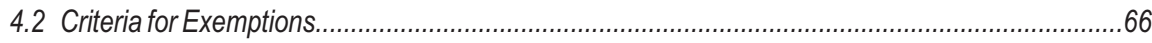

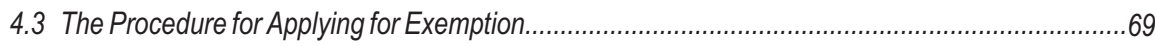

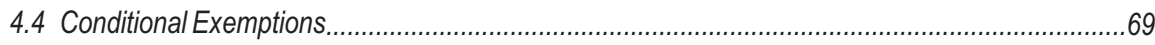

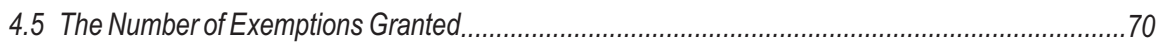

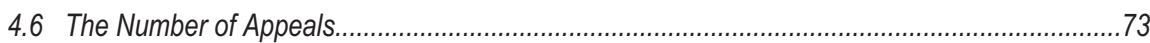

4.7 The Number of Employees Covered by Exemptions......................................................... 74

4.8 The Number of Exemptions Granted to Small Business......................................................... 75

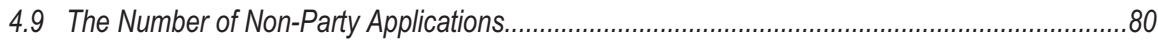

4.10 Previously Unregistered Firms that Apply for Exemption..................................................82

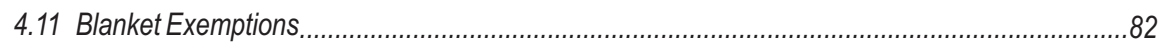

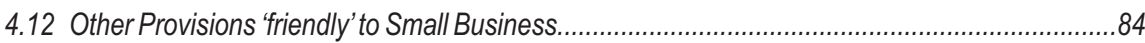

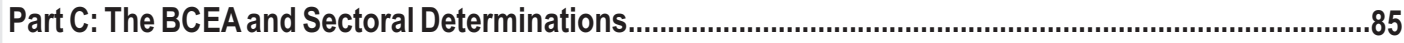

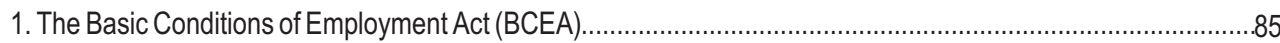

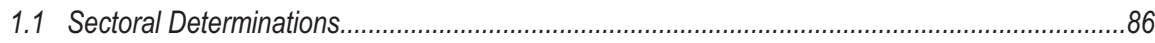

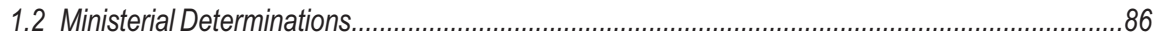

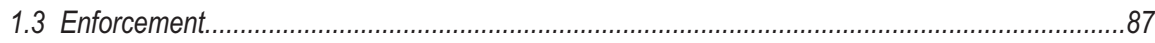

2. Research Findings: The BCEA and Sectoral Determinations................................................................88

2.1 Coverage of the BCEA and Sectoral Determinations...................................................... 88

2.2 Enforcement of, and Compliance with the BCEA and Sectoral Determinations...........................91

2.3 Exemptions (or Variations on Application) from the BCEA .....................................................91 


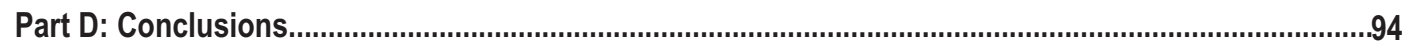

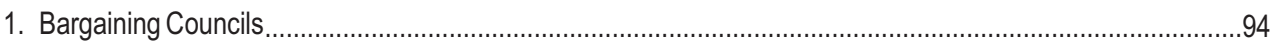

1.1 Bargaining Councils: A System in Crisis? ...........................................................................96

1.2 Some Possible Policy Options.................................................................................................

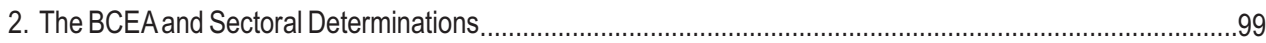

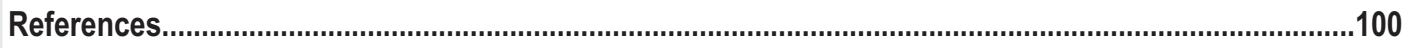

Annexure A 


\section{Executive Summary}

There are about 9.5 million employees in the country that are covered by the Labour Relations Act (LRA) and Basic Conditions Employment Act (BCEA). Of these, about 25 per cent are covered by bargaining council agreements and about 36 per cent are covered by sectoral determinations. The remaining 39 per cent are covered only by the BCEA (including those covered by ministerial determinations and the 'old' sectoral determinations). Only bargaining councils and sectoral determinations prescribe minimum wages, with bargaining council wages generally above the levels set in sectoral determinations.

\section{Bargaining Councils}

The research underscores the diversity of bargaining councils, and the dangers of making generalisations about them. There are very big councils covering the entire country and a number of sectors and sub-sectors, there are national councils with a fairly narrow sectoral focus, there are regional councils that together cover a reasonable proportion of an industry, and there are small local councils that cover only a few hundred workers. The main agreements of councils also differ. Some are long and extremely complex, full of intricacies built up over years of negotiations, while others are relatively straightforward. The same applies to staffing and benefit funds, which vary considerably from council to council.

Bargaining councils cover just less than a third of employees that are potentially covered by collective bargaining (i.e. people working for someone else in occupational categories 4-9 of the Labour Force Survey). Just less than 5 per cent of all such employees are covered by extended agreements, i.e. are employed at non-parties that are registered with councils. There are only two sectors in which bargaining councils have both a significant presence overall and where the number of employees covered by extended agreements is relatively high, i.e. Manufacturing and Transport. In both cases, however, the proportion of employees in the relevant occupational categories that are covered by extended agreements is below 16 per cent. The above does not mean that bargaining councils do not create problems for small businesses.

In theory the way in which small businesses should address any problems that they have with bargaining councils is by joining or forming employers' organisations and making their voices heard in the mandating process prior to and during negotiations. This should result in agreements that better accommodate the sorts of problems they face. It is this approach that the new LRA endorsed by enjoining all councils to include in their constitutions provision for representation by small and medium businesses. 
The shortcoming of the above provision is that it requires nothing more concrete than an amendment to the constitutions of councils. The Act does not require positive action on the part of councils and their employer parties to recruit small businesses and accommodate them in their mandating processes and in negotiations. The two quantitative requirements in the Act for the extension of agreements - employees of party employers as a proportion of all employees, and members of party trade unions as a proportion of all employees - also do not put pressure on employer parties to organise small firms. An employers' organisation with a minority of large employers can meet the first requirement. A third measure - party employers as a proportion of all employers - would put pressure on employers' organisations to put effort into recruiting and retaining small firms as members.

The bargaining council system as a whole is comfortably representative on the first and second measures (i.e. the ones in section 32 of the Act) but is unrepresentative on the third measure: party employers make up only 41 per cent of all registered employers. As many as 24 councils (out of 41 ) are unrepresentative on the third measure. National councils and other large councils are even less representative on the third measure than the system as a whole (seven of the nine councils in this category are unrepresentative on this measure). It should be emphasised, however, that this is looking at the issue of representivity purely on the basis of numbers.

The data on representivity also points to the relatively low union density in the bargaining council system. While trade unions are representative in the bargaining council system as a whole, at 13 of the 41 councils party trade unions have 50 per cent or less membership amongst employees. Again, national and other large councils fare badly on this measure of repesentivity: seven of the nine councils in this category are unrepresentative on the measure.

In the vast majority of cases the party employers on councils are on average larger than the non-party employers (in employment terms). However, overall the party firms are not particularly big (the average size is 27 employees) and do not outweigh non-party firms by very much (the latter employ on average 11 employees). The data therefore shows that the bargaining council system predominantly covers fairly small firms.

However, the average size of party firms at most of the large national councils is significantly bigger than the average size of non-party firms as well as being much bigger than the average size of party firms at the smaller councils. 
Where party employers are considerably larger than non-party employers - such as at the large national councils - the employer parties tend to also be unrepresentative of all employers. The six national councils at which party employers are on average considerably bigger than non-party employers are all unrepresentative on the third measure (i.e. employer parties as a proportion of all parties), some by a considerable margin. The big national councils therefore appear to rely on employers' organisations dominated by large firms to get their employment representivity up nationally, but the national scope of the councils clearly makes it difficult to organise the many smaller employers in the relevant sector.

Data from the Department of Labour (DoL) shows that at 11 of 27 councils more than 40 per cent of small firms were members of the party employers' organisations. Almost all of the 11 councils are relatively small local or regional councils. At nine councils between 21 per cent to 40 per cent of small firms were members of the party employers' organisation, and at seven councils 20 per cent or less of the small firms were members of the party employers' organisations. Therefore, at a relatively large number of councils a fairly large proportion of small firms are represented on the council. In addition, small firms are generally well organised by party trade unions.

Generally, employers' organisations on large national councils were less representative of small businesses than employers' organisations at smaller regional and local councils. However, the relatively high levels of party trade union membership at small firms was fairly evenly spread across all sizes of council.

Interviews conducted with officials of nine bargaining councils showed that at most of the councils one or more of the employer representatives had been appointed to specifically represent the interests of small firms. Such representation was generally seen as effective, although it was acknowledged that the appointed representatives were in the minority on the council. Most interviewees were aware of the difficulty small firms had in organising amongst themselves and participating in a council, but interviewees drew different conclusions, with some indicating that better organisation would lead to more effective representation whereas others suggested that it was an insurmountable problem with which councils simply had to live.

The interviews indicated that a key factor in the way that some councils had ameliorated tensions around small business representation was the introduction of blanket exemptions for small and/or new firms or a dedicated exemption procedure for small firms. A good example of such an exemption is provided by the Furniture (Northern Region) bargaining council, which provides for the phasing in of new firms that have 10 or less employees to full 
compliance over a period of about three years. The Metal and Engineering council provides a good example of a special exemption procedure for small businesses.

Two methods were used to estimate the number of unregistered firms within the scope of councils. The first was to get council officials to estimate what proportion of employers and employees were unregistered. The estimates indicated that at ten councils the proportion of unregistered to registered employers was 20 per cent or higher, and at five of these councils the estimate was 40 per cent or higher. The second method was to use the LFS data to provide an employment figure for a sector against which a council's data on registration could be compared. For various technical reasons the latter method could be applied to only three councils. This method found that 24 per cent of employees covered by the Clothing Industry bargaining council are employed by unregistered employers, 46 per cent of employees covered by the Textile bargaining council are employed by unregistered employers, and 61 per cent of employees in the tanning and general goods sectors of the Leather bargaining council are employed at unregistered firms. Such levels of non-registration clearly constitute a major problem for the councils. We emphasise, however, that these calculations and the estimates of council officials must be treated with caution.

The above estimates raise the question of how the DoL calculates the representivity of parties to bargaining councils. DoL officials state that they measure representivity with respect to all employees within the jurisdiction of the council and not just employees at registered firms. But this means they run into problem of getting accurate data on the total number of employers and employees that fall within the sectors and regions covered by councils. Such data is not available and this poses a challenge for the whole issue of representivity as the basis for extending agreements.

Enforcement is an issue closely associated with levels of non-registration and non-compliance. The research found that generally bargaining councils did not have a great deal of enforcement capacity. The number of agents (inspectors) employed by councils varied considerably according to the size of the council, with the large national councils employing the most agents (except those that did not extend their agreements) and the small local councils employing the fewest. However, the ratio of employees to agents at the large national councils tends to be much larger than the ratio at the regional and local councils. The smaller local and regional councils also conducted more inspections per agent than the larger national councils and tended to spend considerably more time tracking down unregistered firms. On the other hand, the large national councils issued far more compliance orders, which increased sharply over the period. One could extrapolate from 
these findings that non-compliance and non-registration is greater at large councils than at smaller councils, with more incentive for small firms to not register with the council.

The changes introduced by the new LRA have had an impact on the exemption systems of councils. Most have set up independent bodies to hear appeals (those that have not are probably councils that do not extend agreements), and most have developed criteria for considering exemptions and have published the criteria in their collective agreements. Unfortunately, councils have developed lists of about eight or nine criteria and there is no clarity with regard to how they weigh up the criteria in considering an application for exemption.

The number of exemption applications being received by councils showed a significant rise between 2000 and 2004, with the success rate (exemptions granted in full, partially granted and subject to conditions) above 70 per cent over the period. However, the success rate of applications to large national councils showed a steady decline over the period, while the success rate of applications to regional and small national councils increased from just over fifty percent to almost ninety percent.

Only a small proportion of refused exemption applications are taken on appeal: less than 20 per cent of refusals by councils result in appeals and the total number of appeals is low. The success of appeals tends to be quite low, although in 2004 the success rate increased significantly.

The largest proportion of exemption applications came from small firms: in 2002 and 2004 about two-thirds of all applications were from small firms (as defined by each bargaining council).

The refusal rate for exemption applications from small firms was lower than for all firms and was declining. Data supplied by the DoL revealed a similar refusal rate for small firm applications.

The vast majority of exemption applications came from non-party firms. The refusal rate for applications from non-parties is somewhat higher than the refusal rate from all firms (but the refusal rate was an estimate by respondents rather than based on actual figures). 
The survey found that the largest proportion of exemption applications was with respect to council benefit funds. This was followed by exemptions from the wage clause and other types of exemptions. Few applications were for exemption from the entire agreement. More research is needed to establish why so many applications were made with respect to the benefit funds. One explanation is that firms have set up alternative funds. However, it could be that firms find the costs associated with the benefit funds excessive.

Interviews with council officials indicated that blanket exemptions were instrumental in defusing tensions between big and small firms. However, only a minority of councils have made provision for blanket exemptions. Most of these councils base their categorisation for such exemptions on the size of the firm but there were some that did so according to the type of business. Overall the blanket exemptions do not cover large numbers of workers.

\section{BCEA and Sectoral Determinations}

There are currently nine sectoral determinations that cover just over 1 million employers and almost 3.5 million employees. There is no data on the coverage of ministerial determinations or the wage determinations that were converted to sectoral determinations by the 2002 amendment to the BCEA. The latter determinations, however, are probably so out of date that they have very limited application.

It is unknown what the level of compliance is with the BCEA and sectoral determinations. Arguably there is probably a low level of compliance because of the limited enforcement capacity of the DoL: only 706 inspectors are spread across 10 main offices. According to the DoL the inspectors conducted about 184000 inspections in the period April to December 2004 , which translates into an average of about 347 inspections per inspector per year. Total inspections make up a relatively small proportion of all employers covered by the sectoral determinations let alone the remainder covered by the BCEA.

The argument that there are low levels of compliance is somewhat contradicted by the low number of compliance orders issued by inspectors in 2003 and 2004. However, the low number of compliance orders could also be the result of a relatively low number of inspections compared to the number of employers.

The procedure to apply for a variation determination (i.e. an exemption) and the relevant form have been made public by the DoL, but the guidelines used by DoL to assess applications have not been made public or do not enjoy very wide publicity. 
It is difficult to assess the success rate of applications for variation. Data was obtained for three years. The first two years both appear to be exceptional in that a very high number of applications - mostly related to the Agriculture sectoral determination - were not finalised: in 2002/3 only 25 per cent of all applications were granted (with 72 per cent pending) and in 2003/4 only 16 per cent were granted (with 81 per cent pending). If one leaves out the pending applications and counts only exemptions granted and refused, the success rate was 98 per cent in 2002/3 and 97 per cent in 2003/4. In 2004/5, when there were far fewer pending applications but a large number unaccounted for, 63 per cent were granted and 37 per cent refused.

The biggest category of exemption applications from the BCEA was with respect to the overtime provisions, followed by daily and weekly rest periods. The vast majority of applications for exemption from sectoral determinations were with respect to the Agricultural determination, mostly relating to the wage clause. 


\section{Part A: Introduction}

\section{Background to the Research}

During the 1980s small business began to vociferously oppose labour market regulations, arguing that the regulations threatened the viability of many small firms because they did not take account of the circumstances and problems faced by such businesses. Adding weight to their argument was the increasing level of unemployment and the view that small businesses could generate a significant number of new jobs. Industrial councils were singled out for criticism, especially the mechanism to extend industrial council agreements to non-parties and the exemption system. It was argued that the former allowed industrial councils - with big business dominant on the employer side - to impose their agreements on firms that were not party to the negotiations. Big businesses, the argument went, were reaching agreements with unions that had the effect of eliminating their smaller (non-party) competitors when extended. The counterweight to the extension of agreements - the exemption system - was criticised for being ineffective and/or biased against small firms.

The architects of the 1995 LRA took cognisance of some of the concerns of small businesses. The approach, however, was not to exclude small businesses, but rather to persuade them to participate in the system and in that way secure conditions that better suited them. The new Act therefore provided that all bargaining councils would have to include in their constitutions provision for representation of small and medium enterprises on the council. Furthermore, the Act tried to tighten up the requirements to be met by the parties to bargaining councils before an agreement would be extended: clear quantitative representivity thresholds are set for the extension of agreements; agreements must make provision for an independent body to hear appeals by non-parties against the refusal of an application for exemption; ${ }^{1}$ and, agreements must set out the criteria that will be applied by the independent exemptions body when it considers an appeal and these criteria must be fair and promote the primary objectives of the Act.

The 1997 BCEA also attempted to accommodate small businesses concerns. It provides for a certain amount of variation by the Minister (through ministerial determinations and sectoral determinations), bargaining councils, collective agreement, or individual agreement; the scope for variation tends to narrow as one descends this hierarchy. Furthermore, promulgation of the Act itself was held up while research was conducted to establish whether 
it would impact negatively on small businesses. The outcome of the impact assessment research was a ministerial determination that relaxed certain provisions in the BCEA for businesses employing fewer than ten people.

The President's State of the Nation speech, ANC discussion documents, and a number of press statements indicate that there is a strong perception in a number of quarters that the LRA and BCEA are not sufficiently accommodative of small business problems and interests. A particular concern has been the extension of bargaining council agreements, which in turn implies an inadequately functioning exemption system. It is this concern, we understand, that prompted the request to conduct this research.

\section{Conceptualisation of the Research}

A number of approaches could be adopted to examine whether the current statutory and other mechanisms for setting wages and conditions of employment were not sufficiently accommodative of small businesses. Probably the best approach would be to examine the actual impact of extended bargaining council agreements, sectoral determinations, and the BCEA on a sample of small firms, as well as the experience such firms have when applying for exemptions.

It was, however, not conceivable to conduct such research within the time frame for this project. Instead, we have focused on the laws and institutions themselves, examining their coverage and provisions for exemptions or variation, as well as their capacity to enforce their agreements. We also collected quantitative data in respect of these aspects over the period 2000 to 2004. For example, we have collected information on the nature of the exemption systems at bargaining councils as well as data on the number of exemption applications received, the number granted, the number granted with conditions, the number refused, etc.

\subsection{Coverage and Representivity}

Our approach was that in order to understand how legislation and bargaining council agreements could be impacting on small businesses, one needs to start with an examination of the coverage of the legislation and the various wage setting mechanisms. This will put into perspective the number of employers and employees actually covered by such mechanisms and the numbers that are not covered. We take this examination a step further in the case of bargaining councils by splitting their coverage into total coverage and the proportion of employers and employees covered by the extension of agreements. 
This enquiry involves examining the representivity of bargaining councils, i.e. the number of employers who are members of party employers' organisations as opposed to those that are not (so-called non-parties) as well as the number of employees of party and non-party employers and the number of employees that are members of party trade unions. We sought to break this data down further into the number of small firms that are parties and non-parties, and the numbers that each category employs. This would provide a quantitative view of representivity of bargaining councils and how small firms feature in the negotiation of bargaining council agreements. In-depth interviews sought to add a qualitative dimension to this picture, in order to give some sense of whether quantitative representation translated into actual power within councils.

\subsection{Non-Compliance ${ }^{2}$}

An issue related to coverage and representivity is the level of compliance with the relevant mechanisms. The data on bargaining councils is generally confined to the firms that bargaining councils know about, i.e. those firms that are registered with the council. Similarly, representivity is measured primarily according to how many of the registered firms are members of the party employers' organisations and how many registered firms are not members. What this data does not take account of is the number of unregistered firms (and their employees) operating within the jurisdiction of a council. Adding in data on the number of unregistered firms is important for four reasons. First, it adds some detail to our knowledge about the coverage of bargaining councils. Second, it can give a different perspective on the representivity of bargaining councils. In other words, the proportion of firms that are parties to an agreement could shrink significantly if a large number of non-compliant firms was added to the number of non-party firms.

Third, some measure of the extent of non-registration by firms gives an indication of the capacity of bargaining councils and the Department of Labour (DoL) to enforce agreements and determinations. High levels of non-registration would therefore indicate limited enforcement capacity on the part of the relevant institution. Fourth, and related to the last point, the level of non-registration is also an indication of whether the relevant exemption system is utilised and perceived to be effective. Put simply, if most firms choose not to register with a bargaining council's agreement rather than register and apply for an

2 It is important to note that generally we use the term non-compliance to mean non-registration with bargaining councils. Non-compliance could also mean that a firm is registered with a council but is not complying with one or other aspect of its agreement(s). However, the latter is not an issue we investigated. So, compliance generally refers to registration with a bargaining council and non-compliance refers to non-registration. With regard to the BCEA and sectoral determinations, where registration does not take place, non-compliance would generally mean a firm not complying with the BCEA or the relevant sectoral determination. 
exemption, it suggests there is a problem with the exemption system (or there is a strong perception that there is a problem).

Unfortunately, measuring the extent of non-registration is difficult because the way Statistics SA breaks down sectors is not necessarily the same as the way in which bargaining councils define their industrial scope. This means that in only a few cases can one compare Statistics SA employment data with the coverage of councils in order to get a measure of non-registration.

\subsection{Enforcement}

We did not, however, want to rely only on the above quantitative calculations to get an indication of enforcement capacity and how exemption systems were or were not working. We also sought to examine the latter two issues through a more detailed enquiry at bargaining councils and the DoL. So we asked councils and the DoL about the number of designated agents/inspectors they had, how many inspections were performed, etc. Ultimately we wanted to test how rigorously agreements and determinations were being enforced, because an argument can be made that limited enforcement capacity implies an 'accommodation' of small firms because this allows a proportion of them to ignore regulations with impunity. This enquiry reflects back on the coverage of councils, sectoral determinations, etc. It also reflects on the exemption system.

\subsection{Exemptions (or Variations)}

The exemption (or variation) system is the 'safety valve' allowing all firms to apply for some or other concession with respect to the agreement or determination covering them. Such systems are particularly relevant for small firms because this is the main way in which the legislation accommodates the problems that small firms have in complying with minimum conditions. However, the exemption system is only open to those firms that are complying or seeking to comply with the relevant conditions (albeit asking for certain concessions). The exemption system is not used by those employers who are not complying. Such firms have effectively exempted themselves. We therefore enquired into the working of the exemption and variation systems as well as getting quantitative data the number of exemptions applied for, how many were granted, etc. Again, this data should not be viewed in isolation. It should be examined in the light of the representative position of a council, the level of non-registration, and the capacity of the council to enforce its agreements.

Our conceptual approach was therefore to gather data on coverage, representivity, compliance, enforcement and exemptions because they are all inter-related parts of a system of regulation. Our report presents the available data on each of these aspects and our concluding section seeks to identify some of the connections. 


\section{Methodology}

The research was required to be conducted in a very short period of time. This set a constraint on what research methods could be used and what information could be obtained. Three main research methods were used. Firstly, a questionnaire was sent to the Department of Labour to collect whatever data it has on the range of issues being researched. Follow-ups were done to the Department to clarify certain data it supplied as well as to attempt to fill gaps in the data.

Secondly, a questionnaire was sent to all functioning private sector bargaining councils. Our prior experience of conducting research at bargaining councils made us aware that many councils are reluctant to spend time gathering data and filling out questionnaires. ${ }^{3} \mathrm{We}$ therefore spent considerable time refining the questionnaire so that its data-gathering requirements did not appear too onerous or time-consuming. We also put a lot of effort into introducing the questionnaire to councils and following up in order to deal with queries and prod councils into completing it. This involved a telephone call to all the bargaining councils prior to sending the questionnaire. In this telephone call we identified the correct person to send the questionnaire to at the council and also explained the nature and urgency of the research. The questionnaire was then either faxed or emailed to the council. We thereafter made at least one follow-up telephone call to every council to check on progress, answer any queries and emphasise the deadline for completion and return of the questionnaire. In the end we pushed out the deadline twice by a couple of days each time. In this period we made further follow-up calls to those councils that had not yet submitted their questionnaires.

As mentioned above, questionnaires were sent out to all functioning bargaining councils. The list of councils to which questionnaires were sent was compiled from a list of all registered bargaining councils received from the Department of Labour late in 2003. According to the list there are a total of 58 registered councils. However, the Department indicated that six of the councils on the list were defunct and were in the process of being wound up. We excluded these councils from the research. A further seven of the councils were not included because they do not fall within the private sector. These are the five public sector councils, the local government bargaining council and the Transnet bargaining 
council. ${ }^{4}$ One other council on the list was excluded, namely the National Bargaining Council for the Wood and Paper Sector. This council was registered in May 2005 and would therefore have little of the data we were seeking (although it did participate in the research by providing us with data on representivity). ${ }^{5}$

The list to which questionnaires would be sent therefore comprised 44 bargaining councils. However, in the course of contacting councils prior to sending the questionnaire we established that two of the councils were defunct and one other had to all practical purposes merged with another council (it was being administered by the other council). Questionnaires were therefore sent to 41 bargaining councils, which we believe comprise all the functioning councils in the private sector (see Annexure A). We got 29 completed questionnaires back from councils (although how much data was supplied in response to questions varied from council to council).

Thirdly, we attempted to administer a short interview schedule telephonically at 12 bargaining councils. This aimed at providing more qualitative evidence regarding the dynamics on the council between big and small businesses. The councils were selected using data that we had already compiled on the average size of party and non-party firms in councils. The primary selection criterion was those councils where the average size of party firms was significantly bigger than the average size of non-party firms. This difference would imply conditions where large party firms might be dominating councils and using agreements to eliminate competition from small non-party firms. Ultimately we managed to complete nine of these interviews.

Bargaining councils are very diverse. They range from very large national councils to small local councils. In the report that follows we generally present the data split into three categories, i.e. large national and other large councils; regional and small national councils; and, small regional and local councils, as well as providing data for all the councils. This will give a perspective on the whole system and also highlight the functioning of the major bargaining councils in comparison to the smaller regional and local councils.

4 It should also be noted that these councils do not have their agreements extended so the question of non-parties does not arise. There are also no small firms covered by these councils.

5 It has not yet produced a collective agreement for submission to the Minister. 


\section{Part B: Bargaining Councils}

\section{The Labour Relations Act (LRA)}

Bargaining councils are voluntary centralised bargaining institutions established within a statutory framework provided by the LRA. They can therefore be established only where one or more trade unions and one or more employers' organisations agree to set up a council. In order for councils to be registered the parties to the proposed council must be sufficiently representative of employers and employees within the scope of the proposed council. Once registered the council can have its collective agreements extended if it meets certain requirements. The agreements then apply to all employers and employees within the scope of the council, rather than just the members of the party organisations. Councils must have an exemption system in place for firms that wish to apply for an exemption from some or all provisions in the council's agreement(s). An independent body must be established by the council to hear appeals where exemption applications have been refused. Outside of these key features, councils have a lot of latitude as to the sorts of agreements they produce, how much variation they introduce into agreements, how they police their agreements, and the sorts of services (if any) they offer to firms within their jurisdiction.

The drafters of the new LRA were aware that many small firms opposed the extension of industrial council agreements to non-parties and were unhappy with the exemption systems of councils, but they also had to take account of the demands of trade unions for greater centralisation of collective bargaining. The Act ended by making certain concessions to small firms but without substantially altering the architecture of the framework for centralised bargaining. ${ }^{6}$

\subsection{Representivity: Registration of Bargaining Councils}

Section 29 of the new LRA deals with the registration of bargaining councils. Leaving aside certain formalities, the section requires that the application for registration goes to the National Economic Development and Labour Council (NEDLAC) first for consideration. In terms of Section 29(8) NEDLAC must "consider the appropriateness of the sector and area in respect of which the application is made", and "demarcate the appropriate sector and area in respect of which the bargaining council should be registered". Once this has been done NEDLAC must provide a written report to the registrar. Thereafter the registrar must 
determine whether, amongst other things, "adequate provision is made in the constitution of the bargaining council for the representation of small and medium enterprises", and "the parties to the bargaining council are sufficiently representative of the sector and area determined by NEDLAC or the Minister". ${ }^{7}$

The first of the above questions to be determined by the registrar is a formality that arguably has little consequence in practice, i.e. it requires a change to a bargaining council's constitution without the need for there to be representation of small and medium enterprises on the council (see further below). The second criterion is critical. It should be noted that the term 'sufficiently representative' is not defined. Nor has there been any case law under the new LRA that has given the term concrete meaning in respect of bargaining councils.

Registration of a bargaining council therefore rests largely on the notion of 'sufficient representivity'. One possible change is that NEDLAC now has the authority to first decide on the appropriate sector and area for which the bargaining council should be registered. It could conceivably adjust the sector and area in such a way as to ensure that the parties are actually representative, i.e. by narrowing the sector or area to exclude non-parties. However, prior research by ourselves indicates that NEDLAC does not do this. It interprets its brief as being a more technical determination of the appropriate sector and area and does not go into the representivity of the parties. Supporting this interpretation is the fact that there is no mention in the Act of the registrar being required to provide NEDLAC with information regarding the representative position of the parties (although the Act does refer to the registrar providing NEDLAC with the "application and any objections, responses and further information"). Furthermore, section 29(11)(b) makes it clear that the question as to whether the parties are 'sufficiently representative' is for the registrar to decide. ${ }^{8}$

7 The Minister may demarcate the appropriate sector and area if NEDLAC fails to reach agreement on the demarcation.

8 At this point it would be difficult for the registrar to decide representivity on any other basis than 'sufficiently representative' because the council is only in the process of being established and it is highly unlikely that the parties or the registrar would know the actual representivity of the parties. 


\subsection{Representivity: Extension of Bargaining Council Agreements}

The new LRA has attempted to clarify the position regarding the extension of agreements although there is still a grey area of Ministerial discretion. So the Minister must extend an agreement on the request of a council if certain requirements are met. First, section 32(3) provides that the Minister may not extend a bargaining council agreement unless satisfied that after extension the majority of all employees covered are members of the party trade unions, and the members of the party employers' organisations employ the majority of the employees. The section therefore sets clear quantitative thresholds of representivity for the extension of agreements. ${ }^{9}$

It can be argued that the failure to include a third criterion, namely that the party employers' organisation(s) must represent at least 50 per cent of the total number of employers, biases the threshold against representation by small firms. An employers' organisation that has as its members a few very big firms that employ the majority of employees in an industry will meet the requirements of the section as it stands at present. If the third criterion was included the employers' organisations would be compelled to get more members in order to remain representative. This would require employers' organisations to organise smaller firms and retain them as members, which would in turn force employers' organisation to be more accommodating of small firms' interests.

Section 32 also provides for certain other requirements that must be met before the agreement will be extended. First, a bargaining council agreement cannot be extended by the Minister unless he/she is satisfied that provision is made in the agreement for an independent body to hear appeals against the refusal by the council of a non-party's application for exemption or the withdrawal of an exemption by the council. Second, the collective agreement to be extended must contain criteria that will be applied by the independent body when it considers an appeal (and the criteria must be fair and promote the primary objects of the Act). Finally, the terms of the collective agreement must not discriminate against non-parties. 
Importantly, however, section 32 goes on to give the Minister the discretion to extend an agreement, notwithstanding the parties failure to meet the representivity thresholds, if the parties are "sufficiently representative within the registered scope of the bargaining council" and "the Minister is satisfied that failure to extend the agreement may undermine collective bargaining at sectoral level or in the public service as a whole". As noted above, the criterion of 'sufficient representivity' is not defined in the Act. In determining 'sufficient representivity', we submit that the Minister would primarily take account of how the parties to the council match up to the criteria set out in section 32(3), although there would be nothing to stop the Minister also looking at the membership position of the party employers' organisation(s).

There has been no case law regarding how the Minister should exercise his discretion to extend bargaining council agreements or at what point the Minister is entitled to decide that the failure to extend an agreement will undermine sectoral collective bargaining. ${ }^{10}$ There has also been no research on the extension of agreements under the new Act which could shed some light on these questions. However, it is likely that most council agreements will be extended because it is arguable that non-extension of an agreement will always be a threat to sectoral collective bargaining. Further, the LRA clearly seeks to promote centralised bargaining, an objective that is strongly supported by organised labour. These factors must apply pressure to the Minister to interpret 'sufficiently representative' liberally and to extend agreements. ${ }^{11}$

10 There has however been case law regarding the term "sufficiently representative" in respect of organisational rights. In one instance a union with 22 per cent membership was held to be sufficiently representative. The factors taken into account by the CCMA were that there was no other union at the workplace, the applicant union had been present in the workplace since the employer began operations, and the union was capable of recruiting a majority.(UPUSA v Komming Knitting [1997] 4 BLLR 508 (CCMA)). In another case the CCMA held that a union with 30 per cent representation in the workforce was sufficiently representative. The commissioner stated that the requirement of sufficient representivity should not be determined by numbers alone; a union should be considered sufficiently representative "if it can influence negotiations, the financial interests of those engaged in the industry or peace and stability within the industry or any section of the industry".(SACTWU v Sheraton Textiles (Pty) Ltd [1997] 5 BLLR 662 (CCMA)) On the other hand, the CCMA found that 6 per cent membership in the workplace (defined nationally) did not constitute sufficient representivity for the purposes of acquiring stop-order facilities.(OCGAWU v Woolworths (Pty) Ltd [1999] 7 BALR 813 (CCMA)). Allowing the Minister to extend on the basis that the parties are "sufficiently representative" is recognition that representivity is not purely about numbers.

11 To date the Minister has not refused to extend a bargaining council agreement. But this does not mean that every request for an extension has been granted. In practice, officials within the DoL screen requests for extension, referring back to councils agreements that, for whatever reason, are not suitable for extension (an example of such a council is the SA Road Passenger council, which currently does not have an extended agreement). Thereafter there might be some interaction between the DoL and the relevant council in order to overcome the problems before the agreement is re-submitted. Or the council might withdraw the request. 


\subsection{Representation of Small Businesses}

The new LRA requires the constitution of every bargaining council to provide for "the representation of small and medium enterprises" (section 30(b)). Unfortunately the Act does not provide guidelines as to what form such a provision should take. Nor does it require some minimum level of representation for small and medium firms. It therefore requires nothing more than an amendment to the constitution. The thinking behind the provision was nevertheless sound. It proposes that small business should organise itself and represent its interests in the system rather than lobby against the system from outside it. If more small businesses were to participate in the system it should lead to agreements that better accommodate their concerns. It would also improve the representivity of bargaining councils. $^{12}$

It is possible that the 2002 amendments to the LRA will lead to greater attention being focussed on representation of small firms. Section 54(1)(f), which was introduced in the 2002 amendments, requires bargaining councils to submit to the registrar data regarding small firms that fall within the scope of the council. The information includes the number of people employed by small firms, how many are trade union members, and how many small firms are members of the party employers' organisation(s), as well as data regarding small firms and exemptions (see further below). This detailed data allows the Minister to scrutinise requests for the extension of agreements much more carefully.

12 Recent research by Holtzhausen and Mischke (2004) highlights the importance of the admission criteria of bargaining councils, i.e. the criteria with which employers' organisations or trade unions wishing to join a council must comply. Such criteria can act as a barrier to employers' organisations representing small and medium firms, depending on the nature of the criteria. In all cases the bargaining councils use some measure of representivity as a threshold for admission, but these measures differ considerably. For example, the Cape Building Bargaining Council requires that to gain admission the members of an employers' organisation have to employ at least 500 employees in the industry. This contrasts sharply with the National Textile Bargaining Council, which requires that the paid-up members of the employers' organisation must employ at least 33 per cent of the total number of employees within the scope of the relevant sub-sector. (Holtzhausen and Mischke, 2004: 43-45) In both cases the use of employee numbers rather than number of employer members disadvantages small firms. However, the very high threshold used by the National Textile Bargaining Council makes it almost impossible for an employers' organisation representing small firms to gain admission to the council, whereas the much lower threshold used by the Cape Building Bargaining Council does give such employers' organisations a chance (although the very small size of firms in the industry means that an employers' organisation would probably need to organise a large number of employers). We submit that the thresholds for admission must be set at levels that do not contradict the injunction of section 30(b). It seems that this is something that the Department of Labour has not given much attention to. 


\subsection{Enforcement and Compliance}

The new LRA has probably worsened the situation regarding non-compliance with bargaining council agreements. It de-criminalised non-compliance with agreements and at the same time introduced a new dispute resolution procedure, which should have explicitly included the powers and procedure whereby bargaining councils enforced their agreements. However, it did not do so. This resulted, on the one hand, to legal challenges from firms to bargaining councils when they attempted to enforce their agreements. ${ }^{13}$ On the other hand, the uncertainty regarding enforcement of council agreements possibly led to many firms deciding to take a chance and ignore agreements. ${ }^{14}$ The problem was remedied by the insertion of section 33A in the 2002 amendments to the LRA.

The 2002 amendments should also solve another problem regarding enforcement. The new dispute resolution system through which councils had to enforce agreements proved slow and cumbersome. Bargaining council agents found it extremely difficult to bring non-complying employers to book. When this did happen it was usually only after a long time and a great deal of effort. Amendments to section 33A together with Schedule 10 have given greater powers to designated agents to enter workplaces, gather information and question employees regarding compliance with the bargaining council's agreement(s). In addition, section 33A introduces an explicit and streamlined enforcement procedure: a compliance order followed by arbitration; with the arbitrator having wide powers to order payment of amounts owing, impose fines, charge a party an arbitration fee, and order a party to pay the costs of the arbitration.

While the amendment should deal with the sorts of problems that council agents faced in the past, it is important to note that section 33A appears to give considerable latitude to councils with regard to the enforcement procedure. The section provides that a bargaining council may monitor and enforce compliance with its agreements in terms of section 33A or in terms of a collective agreement concluded by the council. The section goes on to state that a "collective agreement in terms of this section may authorise a designated agent... to issue a compliance order requiring any person bound by that collective agreement to comply with the collective agreement within a specified period" (our emphasis). The section further

13 It had been established, although not without considerable confusion and some controversy, that a council could be a party to arbitration proceedings to enforce its own agreement where an independent body conducted the arbitration. (Du Toit et al, 2003: 268) See, for example, Motor Industry Bargaining Council (Western Cape Region) v COFESA (2001) 22 ILJ 556 (ARB), and Portnet v Le Grange (1999) 20 ILJ 916 (LC).

14 However, we have nothing more than anecdotal evidence to support this contention as well as the apparent growth of non-compliance evidenced by the expanding informal economy. 
provides that the council "may refer any unresolved dispute concerning compliance... to arbitration by an arbitrator appointed by the council" (our emphasis). The use of the non-peremptory 'may' suggests that councils can, via collective agreements, put other enforcement procedures into place. It is difficult to say what such procedures should be. The new system of compliance order followed by arbitration appears to be sound and expeditious. However, should employers find ways of delaying the enforcement procedure, councils can introduce measures to close loopholes and plug gaps as they arise.

\subsection{Non-Standard Employment and Non-Registration}

Informal employment has been growing rapidly. The growth has been facilitated by an increase in sub-contracting, outsourcing and homeworking arrangements, as well as by schemes to turn employees into independent contractors (sponsored in most cases by COFESA). While such arrangements do not necessarily result in firms not registering or complying with agreements or legislation, in many cases this is precisely what the effect is. There has been a significant impact on bargaining councils. Some key councils have collapsed because of their increasingly unrepresentative position (notable amongst these was the Gauteng Building Bargaining Council).

Nothing was done to the framework for bargaining councils to deal with this issue. However, the 2002 amendments introduced a supplementary definition of an 'employee' that provided for seven rebuttable presumptions to establish whether an employment relationship exists. This will have some impact, particularly with regard to the COFESA schemes. ${ }^{15}$ But we believe that the impact will be limited for a number of reasons (we do not propose to examine these in detail in this report).

The 2002 amendments also introduced two new powers for bargaining councils. First, section 28(1)(k) provides that a council now has the power "to provide industrial support services within the sector". The probable intention of this amendment is that bargaining councils become more developmental, offering a range of services to small and medium businesses that will induce them into registering with the council. Second, section $28(1)(I)$ provides that a bargaining council has the power "to extend the services and functions of the bargaining council to workers in the informal sector and home workers". This provision clearly goes with the preceding one: in future councils will extend the support services to informal firms along with its functions, namely the standards set in its agreements and its 
benefit funds. To access the support services the informal firms will need to register and start complying with the council's agreements. It is unclear what the effect of these provisions will be. The intentions are good, but much will depend on the capacity of councils to offer support services as well as extend their policing of agreements into the informal economy.

\subsection{Dispute Resolution}

One other change has had an important impact on the capacity of bargaining councils. The new dispute resolution system introduced by the LRA provides that councils may become accredited to perform conciliations and arbitrations for their sectors. For doing this they receive a subsidy per conciliation or arbitration performed. There have been two implications of this new function for bargaining councils. First, the subsidy has proved inadequate and conducting conciliations and, in particular, arbitrations, has put a drain on bargaining council finances. ${ }^{16}$ Second, many councils have trained their inspectors or agents to perform conciliations and, in some cases, arbitrations. This has obviously placed an additional burden on the inspectorate.

Recent research indicates that bargaining councils view the dispute resolution function as a very important part of their role within a sector. There are two options with regard to how they perform dispute resolution.(Hotzhausen and Mischke, 2004: 65-67) The Metal and Engineering Industry Bargaining Council has contracted out its dispute resolution function in its entirety to an outside agency, while most other councils have retained dispute resolution as an in-house function (although the panels of conciliators and arbitrators include differing proportions of outsiders). Neither route solves the problems of expense and capacity. Indeed the former council acknowledges that it is extremely costly to contract out dispute resolution but it indicated that it did not have the capacity (in terms of staff and skills) to run the dispute resolution function itself.

While the in-house option is less expensive, it still imposes a financial burden on the council (which will vary according to how many outsiders the council has on its conciliation and arbitration panels) and also puts pressure on staff (which will, again, vary according to how many outsiders the council has on its conciliation and arbitration panels). For example, the National Bargaining Council for the Road Freight Industry conducts dispute resolution in-house but with outsiders on its panels because its staff does not have the skills to do 
conciliations or arbitrations. The research therefore indicates that councils are faced with a difficult balancing act in taking on the dispute resolution function in terms of the new LRA.

One way of easing the burden would be to charge a dispute resolution levy (an option that is being investigated by the National Bargaining Council for the Chemical Industry). However, this is likely to raise the ire of small firms, which complain that the costs imposed by bargaining councils are already too high. Alternatively, the new section $33 \mathrm{~A}$ has the potential to reduce costs. A more radical option would be to substantially increase the subsidy to councils or, failing that, transfer the dispute resolution function back to the CCMA.

\subsection{Exemptions}

A number of changes were introduced to the new LRA to deal with the problems around exemptions that had emerged under the old Act. First, as discussed above, a bargaining council agreement cannot be extended unless the Minister is satisfied that provision is made in the agreement for an independent body to hear appeals against the refusal by the council of a non-party's application for exemption or the withdrawal of an exemption by the council. The intention of this change is to restrict the involvement of the council itself in the exemption procedure, thereby making the process more impartial. It is interesting to note that in its original form the new LRA provided that a council needed an independent body to hear all applications for exemption (and not just appeals). This was amended in 1998 to limit the role of the independent exemptions body to appeals only. The pressure for the change apparently came from bargaining councils, because they found the need for an independent body for all applications onerous and expensive.

The second change in the new LRA is that a bargaining council agreement cannot be extended by the Minister unless he/she is satisfied that the agreement contains criteria that must be applied by the independent body when it considers an appeal, and that those criteria are fair and promote the primary objects of the Act. The intention of the change is to introduce greater clarity and certainty regarding the standard against which exemption applications are judged.

Research by Holtzhausen and Mischke (2004: 62-64) indicates that bargaining councils have introduced greater clarity regarding the criteria for exemptions and in some cases a more rigorous process to evaluate applications. Importantly, the criteria of some councils now explicitly include the size of the firm and whether it is a new firm. But long lists of criteria raise the question of how a council balances the various criteria in assessing an application for exemption. While the list of criteria give a small business greater clarity on the standards against which its application will be judged, such a list still leaves a lot of room for interpretation by the council or its exemptions sub-committee. So, there are still questions 
about how the councils interpret the exemption criteria, what the impact has been of the independent appeals committee, whether more exemptions are now being granted, and what small firms think of the new system.

Finally, section $30(1)(k)$ requires that a bargaining council constitution must provide the procedure for exemptions from collective agreements. This might clarify the procedure but it is likely that it does little more than set out the basic framework.

\subsection{Data Collected by the Department of Labour}

The LRA requires bargaining councils to submit certain data to the Department of Labour. In certain instances these requirements are stated explicitly (ss 49 and 54), in other instances the Act states that the registrar can request information necessary to make a particular decision (s 29(1) in respect of registration), and in other cases the requirement to submit data is implied (s 32 in respect of the extension of agreements).

Councils must therefore provide data in respect of representivity of the parties when applying for registration of the council and when requesting the Minister to extend a collective agreement. Application for registration is done on LRA Form 3.3, which requires the applicant parties to provide the following information in order to assess the representivity of the proposed council:

- The total number of employers within the proposed scope of the council

- The total number of employees within the proposed scope of the council

- The total number of employees within the proposed scope of the council employed by the members of the party employers' organisations

- The total number of employers within the proposed scope of the council that belong to the party employers' organisations

- The total number of employees within the proposed scope of the council that belong to the party trade unions.

An application for the extension of an agreement is done on LRA Form 3.5. The form requires exactly the same information listed above to assess the representivity of the parties. Similarly, a request to extend the period of, or renew, a collective agreement that has to be extended must also be accompanied by the above information (LRA Form 3.6). What is 
interesting about these forms is that they require the total number of employers within the council's scope and they require the total number of employers within the scope that belong to the party employers' organisations. This allows the registrar to assess the representivity of the employers' organisations based on the number of their members rather than on the number of employees their members employ. Section 32 of the LRA, however, has not included this measure in its test for representivity.

A similar discrepancy occurs in respect of section 49. Section 49(2) requires that a bargaining council that has an extended agreement must inform the registrar annually in writing on a date determined by the registrar as to the number of employees who are:

- Covered by the collective agreement

- Members of the party trade unions

- Employed by members of the party employers' organisations.

Section 49(3) provides that the registrar can request from any council, within a specified period, information regarding the number of employees who are:

- Employed within the registered scope of the council

- Members of the party trade unions

- Employed by members of the party employers' organisations.

However, the two forms on which such information must be supplied (LRA Form 3.20A in respect of section 49(2) and LRA Form 3.20 in respect of section 49(3)) require the same five pieces of information listed above, that is:

- The total number of employers within the proposed scope of the council

- The total number of employees within the proposed scope of the council

- The total number of employees within the proposed scope of the council employed by the members of the party employers' organisations 
- The total number of employers within the proposed scope of the council that belong to the party employers' organisations

- The total number of employees within the proposed scope of the council that belong to the party trade unions.

So, again, the forms ask for information on the number of employers covered and number of members of the party employers' organisations, which the Act does not require.

Finally, the 2002 amendment to the LRA introduced a requirement (in section 54(2)(f)) for councils to provide the registrar with the following information:

- The number of employees that are employed by small enterprises within the scope of the council and the number of employees of those enterprises who are members of trade unions

- The number of employees employed by small enterprises that are covered by the extension of an agreement (presumably this refers to the number of employees of non-party small enterprises)

- The number of small enterprises that are members of the employers' organisations that are parties to the council; and

- The number of applications for exemptions received from small enterprises and the number of applications that were granted and the number rejected.

Again, the form on which the data must be supplied (LRA Form 3.20B) goes beyond the scope of the above section and asks for more information. It requests the above information as well as:

- The total number of employers and employees within the scope of the council

- The number of small enterprises within the scope of the council

- The number of small enterprises covered by an extended agreement (presumably this refers to the number of non-party small enterprises) 
- The number of employees of small enterprises that are members of the party employers' organisations

- The number of applications for exemption broken down into applications from parties and non-parties, each of which is further broken down into six size categories (based on number of employees) and indicating the number granted, refused, and still under consideration.

- The number of seats allocated to small enterprises on the council and the total number of seats on the council

- The number of seats allocated to small enterprises on the council's exemptions board and the total number of seats on the board

- The number of seats allocated to small enterprises on the boards of the council's funds and the total number of seats on these boards.

It is unclear for what purpose this data will be used. There is certainly nothing in the section that indicates that the Minister will use this information to assess requests for extension of agreements. But it is likely that the Minister will take this information into account when considering a request for the extension of an agreement from a council that does not meet the primary requirements in section 32. However, if the intention was that the Minister exercise his/her discretion on the basis of this data then the Act should have made this explicit.

Of course, there is a difference between what the LRA requires bargaining councils to submit to the registrar and what they actually do submit. Section 54(4) of the LRA gives the registrar extensive powers to deal with defaulters. Such powers are obviously not required in order to get the information needed for the registration of bargaining councils and the extension of agreements. If the necessary information is not submitted in these cases the sanction is simply not to grant the registration and the extension. With regard to the data required in terms of sections 49 and 54 , the registrar may:

- Conduct an inquiry into the affairs of the defaulting council

- Order the production of the council's financial records and any other relevant documents 
- Deliver a notice to the council requiring the council to comply with the provisions concerned

- Compile a report on the affairs of the council

- Submit the report to the Labour Court in support of any application for the winding up of the council.

It is not known whether the registrar has ever invoked these powers in order to get information.

The DoL was able to provide a reasonable amount of the data on bargaining councils. But closer scrutiny of some of the data reveals some inconsistencies and gaps as well as some out of date data. However, these are relatively minor points. The major problem regarding this data is that it is not made easily accessible to the public. Much of this data is important for the debate on bargaining councils and their impact on the labour market. The Department should be publishing it on a regular basis.

\section{Research Findings: Bargaining Council Coverage and Representivity}

\subsection{Bargaining Council Coverage}

In the section below we deal with the coverage of bargaining councils. Our primary source of data was the questionnaire survey sent out to all functioning private sector councils. Gaps in the data were filled by information supplied by the DoL as well as data that we had gathered when doing prior research. The data for most councils is up to date as at 2004 but there are a few councils for which we only have somewhat out-of-date data; in a few cases the data is as old as 1999. These were councils that did not respond to the questionnaire and for which the DoL's data is out of date. The reasons that the Department's data is out-of-date is that these councils either do not publish agreements in the Government Gazette or do not extend agreements, which means they seldom submit representivity data to the DoL. However, it is very unlikely that updated data for these councils would differ much from the 'old' data. If there have been changes in the number of employers and employees in the last five years they were almost certainly small. 
All bargaining councils (i.e. including the public sector councils, the local government council and Transnet) cover 20.3 per cent of the total labour force (excluding only the Defence Force) as estimated by the Labour Force Survey (LFS) in September $2004 .^{17}$ The number of employees covered by extended agreements amounts to 2.9 per cent of the labour force. However, this gives a somewhat incorrect picture because the coverage of bargaining councils is being compared to employers, the self-employed and employees, including many who fall outside of the range of occupations covered by bargaining council agreements as well as employees in sectors such as the private household sector that are unlikely to ever have collective bargaining or a bargaining council. In Table 1 we break down bargaining council coverage into those sectors that have a bargaining council or that could conceivably have a council, and we compare the figures with the LFS data for employees in occupational categories 4-9, i.e. the occupational categories that generally would fall within bargaining councils' bargaining units. 
Table 1: Bargaining Council Coverage by Main Industry Classification Using the LFS September 2004

\begin{tabular}{|c|c|c|c|c|}
\hline Industry classification & $\begin{array}{l}\text { Total employees } \\
\text { in grades } 4-9\end{array}$ & Bargaining councils & $\begin{array}{l}\text { Registered } \\
\text { employees }\end{array}$ & $\begin{array}{l}\text { Employees at } \\
\text { non-party firms }\end{array}$ \\
\hline \multirow{3}{*}{$\begin{array}{l}\text { 1. Agriculture, hunting, } \\
\text { forestry and fishing }\end{array}$} & & Fishing & 2516 & 385 \\
\hline & & Grain Co-operative & 8006 & 0 \\
\hline & 688620 & Total & $10522(1.5 \%)$ & $385(0.06 \%)$ \\
\hline 2. Mining and quarrying & 376501 & - & - & - \\
\hline \multirow{12}{*}{ 3. Manufacturing } & & Canvas (x2) & 1908 & 600 \\
\hline & & Chemical & 72691 & 0 \\
\hline & & Clothing & 97958 & 47449 \\
\hline & & Diamond Cutting & 1941 & 74 \\
\hline & & Furniture $(x 6)$ & 26457 & 10225 \\
\hline & & Jewellery & 620 & 140 \\
\hline & & Leather & 17841 & 4823 \\
\hline & & Metal \& Engineering & 272796 & 121672 \\
\hline & & New Tyre & 5150 & 0 \\
\hline & & Sugar & 4947 & 0 \\
\hline & & Textile & 23876 & 4270 \\
\hline & 1230177 & Total & $526185(42.8 \%)$ & $189253(15.4 \%)$ \\
\hline $\begin{array}{l}\text { 4. Electricity, gas and } \\
\text { water supply }\end{array}$ & 59207 & - & - & - \\
\hline \multirow{3}{*}{ 5. Construction } & & Building (x5) & 25748 & 10548 \\
\hline & & Electrical & 21304 & 9937 \\
\hline & 594780 & Total & $47052(7.9 \%)$ & $20485(3.4 \%)$ \\
\hline \multirow{6}{*}{$\begin{array}{l}\text { 6. Wholesale and } \\
\text { retail trade }\end{array}$} & & Commercial Distrib. & 780 & 330 \\
\hline & & Meat Trade & 3350 & 1616 \\
\hline & & Motor & 154655 & 58271 \\
\hline & & Restaurant \& Catering & 18000 & 751 \\
\hline & & Tearoom & 15241 & 3000 \\
\hline & 1333239 & Total & $192026(14.4 \%)$ & $63968(4.8 \%)$ \\
\hline
\end{tabular}




\begin{tabular}{|c|c|c|c|c|}
\hline \multirow{4}{*}{$\begin{array}{l}\text { 7. Transport, storage } \\
\text { and communication }\end{array}$} & & Motor Ferry & 1200 & 300 \\
\hline & & Road Freight & 71628 & 40973 \\
\hline & & SA Road Passenger & 28800 & 12972 \\
\hline & & Transnet & 184488 & 0 \\
\hline & 397669 & Total & $286116(71.9 \%)$ & $54245(13.6 \%)$ \\
\hline \multirow{3}{*}{$\begin{array}{l}\text { 8. Financial } \\
\text { intermediation, } \\
\text { insurance, real estate } \\
\text { and business services }\end{array}$} & & & & \\
\hline & & - & 10040 & \\
\hline & 671601 & Total & $10543(1.6 \%)$ & $1290(0.2 \%)$ \\
\hline \multirow{5}{*}{$\begin{array}{l}\text { 9. Community, social } \\
\text { and personal services }\end{array}$} & & Entertainment & 3700 & 2157 \\
\hline & & Hairdressing (x4) & 7789 & 2924 \\
\hline & & Laundry (x2) & 2110 & 713 \\
\hline & & Local Government & 196000 & 0 \\
\hline & & Public Sector (x5) & 1075969 & 0 \\
\hline & 1890157 & Total & $1285568(68.0 \%)$ & $5794(0.3 \%)$ \\
\hline \multirow{2}{*}{ Overall totals } & 7241951 ** & \multirow{2}{*}{$\begin{array}{l}48 \text { bargaining } \\
\text { councils }\end{array}$} & $2358012^{* * *}$ & 335420 \\
\hline & & & $(32.6 \%)$ & $(4.6 \%)$ \\
\hline
\end{tabular}

* The Electrical Bargaining Council falls into Construction (the contracting part) and the Wholesale and Retail Trade (the service part). For convenience we have classified it under Construction.

** The total employment figure includes only those working for someone else and earning remuneration in the following occupational categories: Clerks, Service workers and shop and market sales workers, Skilled agricultural and fishery workers, Craft and related trades workers, Plant and machine operators, Elementary occupations. This includes formal and informal employment (as defined by Statistics SA). Excluded from the figures are the top three occupational categories as well as employment in private households, employment at extraterritorial organisations and foreign governments, those respondents that could not be adequately specified, and those that were unspecified. Also excluded is the SA Defence Force (it is not covered by the LRA). But it should be noted that the employment figure for the Community, social and personal services sector is for the above six occupational categories as well as the Professionals and Technical and associate professionals categories. This is because the public service councils, which dominate this sector, include these occupational categories in their bargaining units.

\# Employment figures are from the Labour Force Survey, September 2004.

\#\# The figures in respect of bargaining councils are primarily from the survey of private sector councils. Gaps in the data were filled by information supplied by the Department of Labour and by telephoning the relevant bargaining councils. It should be noted that the data from the Department is not consistently up to date as at 2004 . However, this is the case for only a few councils and in general such data is post-2000 
Table 1 shows that 32.6 per cent of all workers that are in occupational categories that would normally be covered by collective bargaining are covered by bargaining councils. Only 4.6 per cent of such workers are employed at non-party employers, i.e. they are covered by the extension of agreements.

Four of the nine major sectors of the economy have no bargaining council or the bargaining councils cover an insignificant proportion of workers. A further two sectors (Construction, Wholesale and Retail) have very low coverage by bargaining councils (less than 15 per cent in both cases) and almost insignificant coverage by extended agreements (less than 5 per cent in both cases). In only three cases do bargaining councils cover a significant proportion of the sector (Manufacturing, Transport, and Community, etc. services), and in the latter two cases it is mainly because of Transnet and the local government and pubic sector councils that the coverage is significant. In the case of the Community services sector, the fact that the public sector councils and local government council do not extend their agreements means that coverage is fairly extensive but the number of workers covered by extended agreements is insignificant.

In only two sectors (i.e. Manufacturing and Transport - both of which are dominated by a handful of large national councils) is coverage fairly extensive and the coverage by extended agreements is significant. And even in these cases employment at non-parties is less than 16 per cent of total coverage. 


\subsection{The Representivity of Bargaining Councils}

The fact that bargaining councils do not cover a large proportion of the specified labour force and that extended agreements cover only a very small proportion is an important finding. It does not, however, mean that the issue of the representivity of bargaining councils is no longer of importance. Within the areas and sub-sectors covered by bargaining councils the question of representivity remains crucial. However, the data regarding overall coverage does put this question into a reduced perspective.

In Table 2 we provide representivity data for all functioning private sector councils, split into three categories (i.e. large national and other large councils; regional councils and small national councils; and, small regional and local councils). There are five sets of data in the table which provide three measures of representivity. The five sets of data are total employers, total employees, party employers, employees at party employers, and members of party trade unions. The three measures of representivity are party employers as a proportion of all registered employers, the number of (covered) employees at party employers as a proportion of all (covered) employees, and members of party trade unions as a proportion of all (covered) employees. As noted above, it is only the latter two measures that are included in section 32 of the LRA regarding the extension of bargaining council agreements. 
Table 2 (a): Bargaining Council Representivity: Total for all Bargaining Councils

\begin{tabular}{|l|l|l|l|l|l|l|l|}
\hline $\begin{array}{l}\text { Bargaining } \\
\text { councils }\end{array}$ & $\begin{array}{l}\text { Total } \\
\text { employers }\end{array}$ & $\begin{array}{l}\text { Party } \\
\text { employers }\end{array}$ & $\begin{array}{l}\text { Party e/ers as } \\
\% \text { of all e/ers }\end{array}$ & $\begin{array}{l}\text { Total } \\
\text { employees }\end{array}$ & $\begin{array}{l}\text { Employees of } \\
\text { party e/ers }\end{array}$ & $\begin{array}{l}\text { Party e/er } \\
\text { employees as \% } \\
\text { of all e/ees }\end{array}$ & $\begin{array}{l}\text { Party union } \\
\text { members }\end{array}$ \\
\hline TOTAL & 50691 & 20865 & 41 & 901555 & 564454 & 63 \\
all e/ees
\end{tabular}

*** The Wood and Paper Sector bargaining council has not been counted in the total above as it was registered in 2005 . It has 36 party employers of a total of 146 employers ( 25 per cent); the employer parties employ 25484 of 43256 employees covered by the council ( 59 per cent); and, the party trade unions have 23355 members ( 54 per cent). Note that the figures for total number of employers and total number of employees are estimates made by the DoL registrar.

\section{Table 2 (b): Bargaining Council Representivity: Large National Councils and other Large Councils}

\begin{tabular}{|c|c|c|c|c|c|c|c|c|}
\hline $\begin{array}{l}\text { Bargaining } \\
\text { councils }\end{array}$ & $\begin{array}{l}\text { Total } \\
\text { employers }\end{array}$ & Party employers & $\begin{array}{l}\text { Party e/ers as } \\
\% \text { of all e/ers }\end{array}$ & Total employees & $\begin{array}{l}\text { Employees of } \\
\text { party elers }\end{array}$ & $\begin{array}{l}\text { Party e/er } \\
\text { employees as \% } \\
\text { of all e/ees }\end{array}$ & $\begin{array}{l}\text { Party union } \\
\text { members }\end{array}$ & $\begin{array}{l}\text { Party union } \\
\text { members as } \\
\% \text { of all e/ees }\end{array}$ \\
\hline Chemical & $240^{*}$ & $240^{*}$ & 100 & $72691^{*}$ & $72691^{*}$ & 100 & 32356 & 44 \\
\hline Clothing & 1175 & 329 & 28 & 97958 & 50509 & 52 & 71239 & 73 \\
\hline Electrical & 5884 & 1608 & 27 & 21304 & 11367 & 53 & 7492 & 35 \\
\hline Leather & 245 & 115 & 47 & 17841 & 13018 & 73 & 13153 & 74 \\
\hline $\begin{array}{l}\text { Metal \& } \\
\text { Engineering }\end{array}$ & 8860 & 2375 & 27 & 272796 & 151124 & 55 & 198123 & 73 \\
\hline Motor & 13720 & 7467 & 54 & 154655 & 96384 & 62 & 70442 & 46 \\
\hline Road Freight & 3301 & 576 & 17 & 71628 & 30655 & 43 & 25681 & 36 \\
\hline
\end{tabular}




\begin{tabular}{|c|c|c|c|c|c|c|c|c|}
\hline $\begin{array}{l}\text { SA Road } \\
\text { Passenger }\end{array}$ & $180^{*}$ & $28^{*}$ & 16 & $28800^{*}$ & $15828^{*}$ & 55 & 13457 & 47 \\
\hline Textile & 137 & 66 & 48 & 23876 & 19606 & 82 & 18466 & 77 \\
\hline TOTAL & 33742 & 12804 & 38 & 761549 & 461182 & 61 & 450409 & 59 \\
\hline
\end{tabular}

* The Chemical Industry bargaining council has never had an extended agreement and therefore effectively does not have non-parties (although technically there are non-parties within its registered jurisdiction). We have counted only the party firms, their employees and party trade union members. The SA Road Passenger council has not had its main agreement extended and therefore also does not currently have non-parties. However, the council has in the past had its agreement extended and could again in future have its agreement extended, so we have included data for parties and non-parties.

Table 2 (c): Bargaining Council Representivity: Regional Councils and Small National Councils

\begin{tabular}{|c|c|c|c|c|c|c|c|c|}
\hline Bargaining councils & $\begin{array}{l}\text { Total } \\
\text { employers }\end{array}$ & $\begin{array}{l}\text { Party } \\
\text { employers }\end{array}$ & $\begin{array}{l}\text { Party e/ers as } \\
\% \text { of all elers }\end{array}$ & $\begin{array}{l}\text { Total } \\
\text { employees }\end{array}$ & $\begin{array}{l}\text { Employees of } \\
\text { party e/ers }\end{array}$ & $\begin{array}{l}\text { Party e/er } \\
\text { employees as } \\
\% \text { of all elees }\end{array}$ & $\begin{array}{l}\text { Party union } \\
\text { members }\end{array}$ & $\begin{array}{l}\text { Party union } \\
\text { members as } \\
\% \text { of all } \\
\text { elees }\end{array}$ \\
\hline Building: Cape & 1311 & 244 & 19 & 14672 & 7719 & 53 & 7356 & 50 \\
\hline Building: S\&E Cape & $600^{*}$ & $300^{*}$ & 50 & $6800^{*}$ & $5100^{*}$ & 75 & $2200^{*}$ & 32 \\
\hline Contract Cleaning & 227 & 70 & 31 & 10543 & 9253 & 88 & 5284 & 50 \\
\hline Entertainment & 785 & 159 & 20 & 3700 & 1543 & 42 & 1850 & 50 \\
\hline Fishing & 36 & 18 & 50 & 2516 & 2131 & 85 & 1504 & 60 \\
\hline Furniture: KZN & 291 & 94 & 32 & 4806 & 3413 & 71 & 2663 & 55 \\
\hline Furniture: N Region & 1211 & 197 & 16 & 14162 & 7343 & 52 & 7421 & 52 \\
\hline Furniture: W Cape & 231 & 145 & 63 & 5347 & 4138 & 77 & 5019 & 94 \\
\hline Grain Co-operative & 9 & 9 & 100 & 8006 & 8006 & 100 & 6250 & 78 \\
\hline
\end{tabular}




\begin{tabular}{|l|l|l|l|l|l|l|l|l|}
\hline Hairdressing: Semi-Nat. & 1251 & 641 & 51 & 3970 & 2066 & 52 & 2417 & 61 \\
\hline Meat Trade: Gauteng & 863 & 466 & 54 & 3350 & 1734 & 52 & 2054 & 61 \\
\hline New Tyre & 6 & 6 & 100 & 5150 & 5150 & 100 & 4852 \\
\hline Restaurant & 5500 & 4091 & 74 & 18000 & 17249 & 96 & 94 \\
\hline Sugar & 14 & 14 & 100 & 4947 & 4947 & 100 & 14885 \\
\hline Tearoom: Pretoria & 2065 & 527 & 26 & 15241 & 12241 & 80 & 4947 & 939 \\
\hline TOTAL & $\mathbf{1 4 4 0 0}$ & $\mathbf{6 9 8 1}$ & $\mathbf{4 8}$ & $\mathbf{1 2 1 2 1 0}$ & $\mathbf{9 2 0 3 3}$ & $\mathbf{7 6}$ & $\mathbf{7 8 6 9 1}$ & $\mathbf{6 5}$ \\
\hline
\end{tabular}

* The Building (Southern \& Eastern Cape) bargaining council has not had a main agreement for some years. Therefore, strictly speaking, it does not have parties or non-parties. We have included it in the table because the council still exists (having survived an application by the employer party to have it de-registered) and it seems that collective bargaining might still take place on the council.

\section{Table 2 (d): Bargaining Council Representivity: Small Regional and Local Councils}

\begin{tabular}{|c|c|c|c|c|c|c|c|c|}
\hline Bargaining councils & $\begin{array}{l}\text { Total } \\
\text { employers }\end{array}$ & $\begin{array}{l}\text { Party } \\
\text { employers }\end{array}$ & $\begin{array}{l}\text { Party e/ers as } \\
\% \text { of all e/ers }\end{array}$ & $\begin{array}{l}\text { Total } \\
\text { employees }\end{array}$ & $\begin{array}{l}\text { Employees of } \\
\text { party e/ers }\end{array}$ & $\begin{array}{l}\text { Party e/er } \\
\text { employees as } \\
\% \text { of all elees }\end{array}$ & $\begin{array}{l}\text { Party union } \\
\text { members }\end{array}$ & $\begin{array}{l}\text { Party union } \\
\text { members as } \% \\
\text { of all e/ees }\end{array}$ \\
\hline Building: Bloemfontein & 105 & 38 & 36 & 1650 & 865 & 52 & 1060 & 64 \\
\hline Building: Boland & 375 & 133 & 35 & 2200 & 1247 & 57 & 1398 & 64 \\
\hline Building: Kimberley & 72 & 29 & 40 & 426 & 269 & 63 & 245 & 58 \\
\hline Canvas: Cape & 22 & 18 & 82 & 1082 & 894 & 83 & 270 & 25 \\
\hline $\begin{array}{l}\text { Canvas: Wits \& } \\
\text { Pretoria }\end{array}$ & 65 & 35 & 54 & 826 & 414 & 50 & 414 & 50 \\
\hline
\end{tabular}


Conditions of Employment and Small Business: Coverage, Compliance and Exemptions

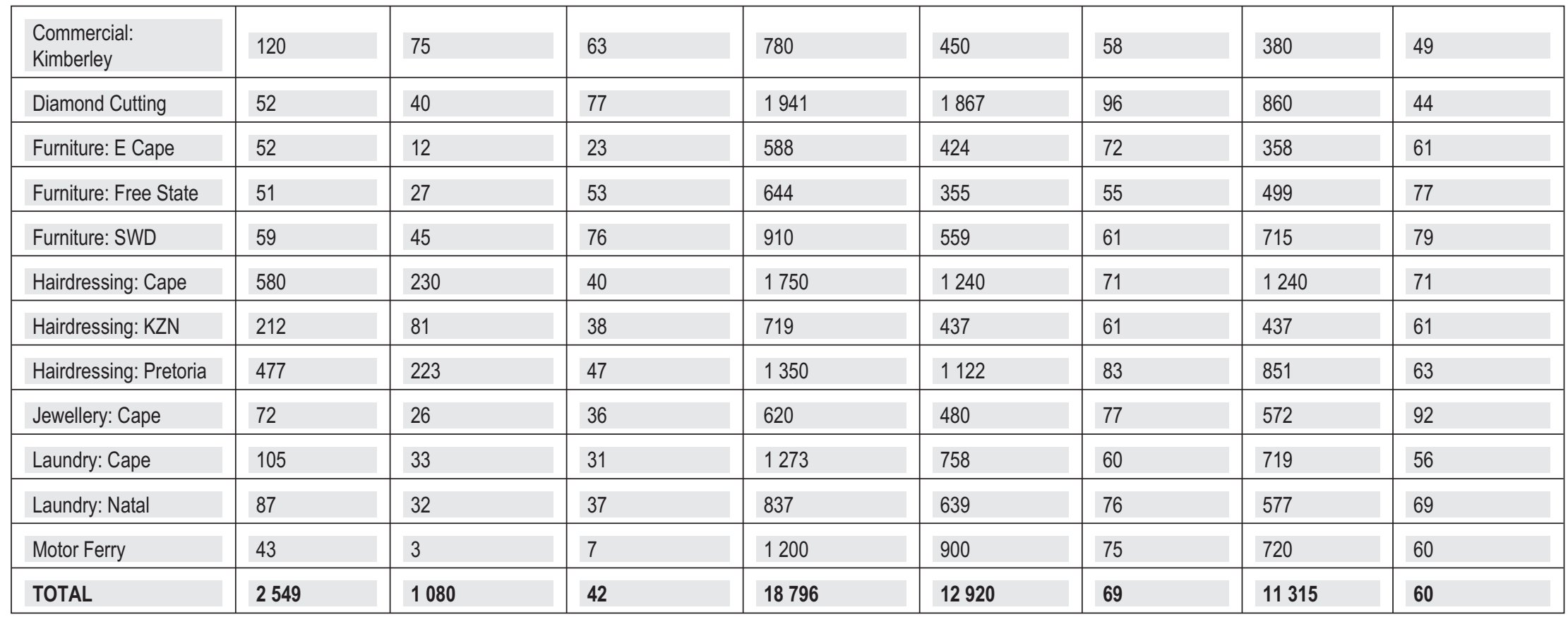


The table shows that overall the private sector councils are representative on the two measures in section 32 of the LRA. Party employers employ 63 per cent of all employees covered by councils and 60 per cent of all employees covered by councils are members of trade unions that are party to councils. But the system appears less representative when one considers the third measure, i.e. party employers as a proportion of all employers: only 41 per cent of employers are members of party employers' organisations. ${ }^{18}$

When one examines the three categories of council one finds that all are representative on the two measures in section 32 of the LRA, but none of the categories are representative on the third measure. However, it is significant that the large national council and other large council category is even less representative on the latter measure than the overall figure (i.e. 38 per cent as against 41 per cent). On the other hand, the regional council category is close to representative on the third measure (48 per cent) and is very representative in terms of the two measures in section 32.

Looking at the data in more detail one finds only two councils out of 41 that have less than 50 per cent representivity when one uses the employment by party employer measure (Road Freight [ a large national council] and Entertainment [a small national council]). The trade union membership measure is more problematic: there are nine councils that have less than 50 per cent representivity on this measure and a further four that are exactly on 50 per cent. The large national and other large council category fares particularly badly on the latter measure, accounting for five of the nine unrepresentative councils.

Councils fare by far the worst on the third measure, i.e. members of party employers' organisations as a proportion of all registered employers. In the latter case 24 bargaining councils are less than 50 per cent representative, and in a number of cases representivity on this measure falls well below 50 per cent (e.g. there are 11 bargaining councils that have employers' organisations that represent fewer than 30 per cent of all registered employers). Again, the large national and other large council category features prominently: seven of the nine councils in this category are unrepresentative on this measure. The small regional and local council category is also significantly unrepresentative with regard to this measure, with 11 of 17 councils unrepresentative.

18 Note that we are here referring to representivity purely in terms of whether the parties' members make up 50 per cent or more of the employers. CCMA decisions with respect to organisational rights make it clear that representivity is not just a question of numbers. See discussion in footnote 10 above. 


\subsection{Bargaining Council Representivity and Size of Firms}

When one puts together the results of the first measure, i.e. total employment by party employers, with the results of the last measure, i.e. party employers as a proportion of all employers, then one gets an indication that the employer side of many bargaining councils is made up of larger employers in employers' organisations that are not representative of all employers. One can examine this finding in more detail by looking at the average size of party employers and non-party employers for each council, using the number of employees as the size criterion. 
Table 3 (a): The Average Size of Party Firms, Non-Party Firms and all Registered Firms: All Bargaining Councils

\begin{tabular}{|l|l|l|l|}
\hline Bargaining councils & Average size of all registered firms & Average size of party firms & Average size of non-party firms \\
\hline AVERAGE & 18 & 27 & 11 \\
\hline
\end{tabular}

* The Wood and Paper Sector bargaining council has not been included in the average as it was registered in 2005. The average size of all registered firms covered by the council is 296 , with the average size of party firms standing at 708 and non-party firms at 162 .

Table 3 (b): The Average Size of Party Firms, Non-Party Firms and All Registered Firms: Large National and Other Large Councils

\begin{tabular}{|c|c|c|c|}
\hline Bargaining councils & Average size of all registered firms & Average size of party firms & Average size of non-party firms \\
\hline Chemical & 303 & $\mathrm{n} / \mathrm{a}$ & $\mathrm{n} / \mathrm{a}$ \\
\hline Clothing & 83 & 153 & 56 \\
\hline Electrical & 4 & 7 & 2 \\
\hline Leather & 73 & 113 & 37 \\
\hline Metal \& Engineering & 31 & 64 & 19 \\
\hline Motor & 11 & 13 & 9 \\
\hline Road Freight & 22 & 53 & 15 \\
\hline iOSA Road Passenger & 160 & 565 & 85 \\
\hline Textile & 174 & 297 & 60 \\
\hline AVERAGE & 23 & 36 & 14 \\
\hline
\end{tabular}


Table 3 (c): The Average Size of Party Firms, Non-Party Firms and all Registered Firms: Regional Councils and Small National Councils

\begin{tabular}{|l|l|l|l|}
\hline Bargaining councils & Average size of all registered firms & Average size of party firms & Average size of non-party firms \\
\hline Building: Cape & 11 & 32 & 7 \\
\hline Building: S\&E Cape & 11 & 17 & 6 \\
\hline Contract Cleaning & 46 & 132 & 8 \\
\hline Entertainment & 5 & 10 & 3 \\
\hline Fishing & 70 & 118 & 21 \\
\hline Furniture: KZN & 17 & 36 & 7 \\
\hline Furniture: N Region & 12 & 37 & 7 \\
\hline Furniture: W Cape & 23 & 29 & 14 \\
\hline Grain Co-operative & 890 & n/a & n/a \\
\hline Hairdressing: Semi-Nat. & 3 & 3 & 3 \\
\hline Meat Trade: Gauteng & 4 & 4 & 4 \\
\hline New Tyre & 858 & n/a & n/a \\
\hline Restaurant & 3 & 4 & 1 \\
\hline Sugar & 353 & n/a & n/a \\
\hline Tearoom: Pretoria & 7 & 23 & 2 \\
\hline AVERAGE & 8 & 13 & 4 \\
\hline
\end{tabular}


Table 3 (d): The Average Size of Party Firms, Non-Party Firms and all Registered Firms: Small Regional and Local Councils

\begin{tabular}{|c|c|c|c|}
\hline Bargaining councils & Average size of all registered firms & Average size of party firms & Average size of non-party firms \\
\hline Building: Bloemfontein & 16 & 23 & 12 \\
\hline Building: Boland & 6 & 9 & 4 \\
\hline Building: Kimberley & 6 & 9 & 4 \\
\hline Canvas: Cape & 49 & 50 & 47 \\
\hline Canvas: Wits \& Pretoria & 13 & 12 & 14 \\
\hline Commercial: Kimberley & 7 & 6 & 7 \\
\hline Diamond Cutting & 37 & 47 & 6 \\
\hline Furniture: E Cape & 11 & 35 & 4 \\
\hline Furniture: Free State & 13 & 13 & 12 \\
\hline Furniture: SWD & 15 & 12 & 25 \\
\hline Hairdressing: Cape & 3 & 5 & 2 \\
\hline Hairdressing: KZN & 3 & 5 & 2 \\
\hline Hairdressing: Pretoria & 3 & 5 & 1 \\
\hline Jewellery: Cape & 9 & 19 & 3 \\
\hline Laundry: Cape & 12 & 23 & 7 \\
\hline Laundry: Natal & 10 & 20 & 4 \\
\hline Motor Ferry & 28 & 300 & 8 \\
\hline AVERAGE & 7 & 12 & 4 \\
\hline
\end{tabular}


The table confirms that in the case of the vast majority of councils the party firms are larger on average than the non-party firms, with the result that the overall average size of party firms is larger than non-party firms. However, the average size of party firms (27 employees) it not that much bigger than party firms (11 employees). In fact, the average sizes of all firms, party firms and non-party firms are relatively small. This is an important finding: when looking at the average sizes the bargaining council system is by and large a regulator of fairly small firms.

Breaking the data down into the three categories of council produces an interesting result. It appears that the smaller the council the smaller the average firm size. While the average size difference is marginal between the regional and small national council category and the small regional and local council category, the difference is more marked in respect of the large national and other large council category. When one examines that data in more detail the reason for this becomes clearer. The average size of party firms at many of the large councils is significantly bigger than in the other categories. It is only councils that cover sectors in which small and micro firms predominate, such as the Motor Council and the Electrical Council, that the average size of party firms is small and there is little difference in the average size of party and non-party firms. At the remaining councils in this category the average size of party firms is much bigger and there is a significant difference in the average size of party and non-party firms.

There are also substantial differences in the average size of party and non-party firms in the regional and small national council category but this is the case for only two councils. At almost all the other councils the differences are not great and firms are generally fairly small. This is even more so the case for the small regional and local council category, with the exception of the Motor Ferry Council.

\subsection{DoL Data on Small Business Representation on Councils}

Data supplied for the DoL provides further insight on the issue of small businesses covered by councils and their representation. The data must be treated with caution. There are a number of gaps in the data supplied by the DoL and some councils on the original table have been left out because the data was incomplete or did not make sense. There are a few more obvious questions that one can raise about the data. For example, how is it possible for councils to supply data on small businesses within their jurisdictions when they do not appear to have defined a small business? The data on the number of seats on councils raises another question: it is not always clear whether councils are providing figures for all seats (i.e. employer and trade union seats) or whether the figures are for the employer seats only. 
In Table 4 we provide the data broken down into the three categories of bargaining councils.

Table 4(a): Department Of Labour Data On Representation of Small Firms on Bargaining Councils: Large National and other Large

\begin{tabular}{|c|c|c|c|c|c|c|c|}
\hline Bargaining council & $\begin{array}{l}\text { Definition of small } \\
\text { firm }\end{array}$ & Total small firms & $\begin{array}{l}\text { Employees of } \\
\text { small firms }\end{array}$ & $\begin{array}{l}\% \text { of small firms } \\
\text { that are parties }\end{array}$ & $\begin{array}{l}\% \text { of small firm } \\
\text { non-parties }\end{array}$ & $\begin{array}{l}\% \text { party union } \\
\text { members at small } \\
\text { firms }\end{array}$ & $\begin{array}{l}\text { Small firm } \\
\text { seats on } \\
\text { council }\end{array}$ \\
\hline Electrical & Not provided & 1755 & 6061 & 47 & 53 & 73 & 14 of 27 \\
\hline Motor & 10 or less employees & 12085 & 52572 & 31 & 69 & 12 & 1 of 4 \\
\hline Road Freight & 2 or less drivers & 932 & 874 & 3 & 97 & 83 & 1 of 12 \\
\hline Textile & 15 or less employees & 13 & 127 & 8 & 92 & 24 & 2 of 22 \\
\hline
\end{tabular}


Table 4 (b): Department Of Labour Data on Representation of Small Firms on Bargaining Councils: Regional and Small National Councils

\begin{tabular}{|c|c|c|c|c|c|c|c|}
\hline Bargaining council & $\begin{array}{l}\text { Definition of small } \\
\text { firm }\end{array}$ & Total small firms & $\begin{array}{l}\text { Employees of } \\
\text { small firms }\end{array}$ & $\begin{array}{l}\% \text { of small } \\
\text { firms that are } \\
\text { parties }\end{array}$ & $\begin{array}{l}\% \text { of small firm } \\
\text { non-parties }\end{array}$ & $\begin{array}{l}\% \text { party union } \\
\text { members at } \\
\text { small firms }\end{array}$ & $\begin{array}{l}\text { Small firm } \\
\text { seats on } \\
\text { council }\end{array}$ \\
\hline Building: Cape & 5 or less employees & 630 & 1707 & 5 & 95 & 12 & 8 of 16 \\
\hline Building: S\&E Cape & 5 or less employees & 200 & 1000 & 50 & 50 & 50 & 2 of 8 \\
\hline Contract Cleaning & 50 or less employees & 173 & 807 & 76 & 24 & $\mathrm{n} / \mathrm{a}$ & 2 of 6 \\
\hline Entertainment & $\begin{array}{l}\text { Less than } 10 \\
\text { employees }\end{array}$ & 785 & 3700 & 20 & 80 & 50 & 4 of 12 \\
\hline Fishing & 20 or less employees & 12 & 188 & 25 & 75 & 40 & 2 of 10 \\
\hline Furniture: KZN & NSB Act definition & 244 & 2468 & 30 & 70 & 35 & 3 of 9 \\
\hline Furniture: N Region & 10 or less employees & 825 & 2064 & 10 & 90 & 9 & 1 of 9 \\
\hline Furniture: W Cape & 3 or less employees & 36 & 81 & 64 & 36 & 88 & 1 of 10 \\
\hline $\begin{array}{l}\text { Hairdressing: } \\
\text { Semi-nat }\end{array}$ & 10 or less employees & 1019 & 2697 & 50 & 50 & 47 & 6 of 8 \\
\hline Meat Trade: Gauteng & 50 or less employees & 853 & 2337 & 54 & 46 & 73 & 3 of 15 \\
\hline Restaurant & 7 or less employees & 1751 & 6163 & 32 & 68 & 4 & 0 of 10 \\
\hline Tearoom: Pretoria & Not provided & 2065 & 15241 & 26 & 74 & 80 & 12 of 12 \\
\hline
\end{tabular}


Table 4(c): Department of Labour Data on Representation of Small Firms on Bargaining Councils: Small Regional and Local Councils

\begin{tabular}{|c|c|c|c|c|c|c|c|}
\hline Bargaining council & $\begin{array}{l}\text { Definition of small } \\
\text { firm }\end{array}$ & Total small firms & $\begin{array}{l}\text { Employees of } \\
\text { small firms }\end{array}$ & $\begin{array}{l}\% \text { of small } \\
\text { firms that are } \\
\text { parties }\end{array}$ & $\begin{array}{l}\% \text { of small } \\
\text { firm } \\
\text { non-parties }\end{array}$ & $\begin{array}{l}\% \text { party union members } \\
\text { at small firms }\end{array}$ & $\begin{array}{l}\text { Small firm } \\
\text { seats on } \\
\text { council }\end{array}$ \\
\hline Building: Bloem & 10 or less employees & 72 & 576 & 21 & 79 & $\mathrm{n} / \mathrm{a}$ & 0 of 6 \\
\hline Building: Boland & Not provided & 43 & 1900 & 44 & 66 & 68 & 2 of 4 \\
\hline Building: E London* & 5 or less employees & 40 & 130 & 95 & 5 & 46 & 1 of 8 \\
\hline Building: Kimberley & 10 or less employees & 40 & 190 & 28 & 72 & 14 & 1 of 6 \\
\hline Canvas Goods & $\begin{array}{l}\text { Less than } 10 \\
\text { employees }\end{array}$ & 13 & 71 & 54 & 46 & 51 & 0 of 8 \\
\hline Diamond Cutting & Not provided & 36 & 274 & 69 & 31 & $\mathrm{n} / \mathrm{a}$ & 0 of 4 \\
\hline Furniture: E Cape & 5 or less employees & 59 & 420 & 20 & 80 & 0 & $\mathrm{n} / \mathrm{a}$ \\
\hline Laundry: Cape & No clear definition & 106 & 1257 & 31 & 69 & 64 & 5 of 10 \\
\hline Laundry: KZN & No clear definition & 86 & 594 & 35 & 65 & 52 & 0 of 6 \\
\hline Meat Trade: E Londn* & 7 or less employees & 4 & 17 & 100 & 0 & $\mathrm{n} / \mathrm{a}$ & 0 of 8 \\
\hline Motor Ferry & Not yet defined & 40 & 200 & 0 & 100 & $\mathrm{n} / \mathrm{a}$ & $\mathrm{n} / \mathrm{a}$ \\
\hline
\end{tabular}

* The Building (East London) and Meat Trade (East London) are included in the DoL data but were not included in the survey conducted by ourselves. The latter council was found to be defunct while the former has to all intents and purposed merged with the Building (S \& E Cape) bargaining council (its data was incorporated into the latter council's data). 
What is somewhat surprising about the data in Table 4 is that it shows that relatively large numbers of small firms covered by bargaining councils are members of the party employers' organisation(s). At 11 out of 27 bargaining councils more than 40 per cent of small firms were members of the party employers' organisation(s) and at nine councils between 21 per cent to 40 per cent of the small firms were members. At only three councils were 5 per cent or less small firms members of the party employers' organisations. This suggests that many small firms are participating in the system rather than just registering with the council (with the caveat that the figures reflect registered small firms only). What makes the finding even more significant is that in general bargaining councils define small firms as very small, i.e. the majority of councils have adopted a definition of 10 or less employees.

The DoL has data for four of the councils in the large national and other large council category. At one of these councils more than 40 per cent of small firms were members of the party employers' organisation and at another 31 per cent of small firms were members of the party employers' organisation. At a third, less than 5 per cent of small firms were members of the party employers' organisation. In the regional and small national councils category, on the other hand, at five of the 12 councils over 40 per cent of small firms were members of the party employers organisation, and a further four were in the 21 per cent to 40 per cent range. The small regional and local council category has a similar breakdown: at five of the 11 councils over 40 per cent of small firms were members of the party employers organisation, and a further four councils were in the 21 per cent to 40 per cent range. The finding suggests that there is greater representation of smaller firms on the employer side of smaller councils.

The data is also surprising in that it shows that small firms are generally well organised by party trade unions. At 13 of the 27 councils, party trade union membership at small firms exceeded 40 per cent. At three other councils party trade union membership was in the 21 per cent to 40 per cent range. Trade union membership at registered small firms therefore appears to be relatively healthy. This undermines somewhat the argument by some small firms that they should not have bargaining council agreements extended to them as they are not members of the employers' organisation and few or none of their employees are organised by party trade unions. While this might be true for the employer it does not appear to be true in about half the cases for the employees. Again, however, one needs to emphasise that the figures reflect trade union membership at registered small firms only. If unregistered small firms could somehow be included, the findings might change significantly.

Unlike with the representation of small firms by employers' organisations, there is a fairly even spread across the three categories of councils in terms of high levels of party union membership at small firms. Two of the four large national councils had party union 
membership in the over 40 per cent range and one was in the 21 per cent to 40 per cent range. In the regional and small national council the breakdown was respectively six and two, and in the small regional and local council category it was five and zero

The table also gives detailed data regarding seats allocated to small business representatives. As noted above, there are some question marks over this data. Furthermore, it requires more qualitative research to go beyond these figures and understand whether these seats actually translate into power in negotiations that would result in some accommodation of small businesses.

\subsection{Qualitative Interviews Regarding Small Business Representation}

In order to go beyond this quantitative representation of the composition of bargaining councils by size of firm, we conducted a short qualitative interview at nine bargaining councils in order to understand what the dynamics are between large and small firms. ${ }^{19}$ The majority of the councils are large national councils and most of the other councils are in the regional and small national council category. ${ }^{20}$

Of the nine councils only one, the Metal and Engineering Bargaining Council had member employers' organisations that specifically represent small businesses. At six of the remaining councils, however, the employers had nominated one or two of the employer representatives to specifically represent small business interests on the council. But at one of the latter councils the employers had indicated that all the representatives represented small business (contrary to the council's constitution which required only one to be nominated for this purpose).

Generally, the councils indicated that the small business representatives did actually try to represent small business interests, and in most cases the representation was seen as effective. But in some cases this view was qualified, in that although the representative(s) did their best to raise small business concerns they were in all cases in the minority, and were often outvoted. Only one bargaining council indicated that the representation was not

19 It should be noted that in some cases the respondent at the council completed and returned the interview schedule without an interview actually taking place. In such cases, follow-up calls were made if any information was unclear.

20 The nine bargaining councils were Metal and Engineering, Contract Cleaning, SA Road Passenger, Road Freight, Clothing, Textile, Building (Cape), Furniture (E Cape), and Furniture (N Region). 
effective (this is the same council at which all the employer representatives had indicated that they represented small business).

Interviewees were asked whether there were any ways in which small business could be more effectively represented. Three councils did not see that such representation could be made more effective. Two councils believed that small business representation could not be more effective because small businesses could not organise themselves and commit time to participation in the bargaining council. Two councils were more optimistic in that they felt that if small businesses did organise themselves (in the case of the Metal and Engineering council into a strong national body) they would more effectively represent themselves. One other council provided a number of suggestions as to how small businesses could be represented:

- There must be a compulsory minimum of one employer and one employee representative on councils to represent small businesses

- The DoL needs to conduct an annual survey of small businesses to identify their needs and problems regarding bargaining councils

- Recognition needs to be given to the number of small businesses represented by employers' organisations rather than how many employees the members employ

- The thresholds (employee numbers or percentages) for admitting new employers' organisation parties should be removed as these are barriers to small business representation

- A bargaining council's definition of small, medium and micro businesses should be reviewed annually by DoL

- Bargaining councils should submit an annual report to DoL on positive steps taken to include and accommodate small businesses in their main agreements

- The extension of a bargaining council agreement should be dependant on complying with the above to the satisfaction of the Minister

Councils were then asked what the big businesses on councils could do to better accommodate small business interests. Almost all the councils indicated that there was nothing more that big businesses could do, or that big business had already accommodated small business to the extent possible (or to the extent that there were no longer tensions between big and small businesses). In the case of six councils the factor motivating the 
above answer was that some form of blanket exemption or special exemption procedure had been introduced to accommodate small businesses. For example, the Metal and Engineering Bargaining Council had made provision for a wage relief exemption, a special exemption for small and struggling businesses, and an expedited exemption procedure for small businesses. In addition, the parties to the council had undertaken to streamline the exemption process further and set up a special, simple and expedited wage exemption process for small business based on the employment size and annual turnover of the business.

The Furniture Bargaining Council (Northern Region) has introduced a sophisticated blanket exemption for newly established businesses that have 10 or less employees. There are four phases to the process which see qualifying firms phasing in to full compliance over about a three year period. The process does not exclude individual applications for exemption, which means that a firm could extend the period of the phase-in on application. The council believe that this is responsible for defusing almost all tensions between small businesses and the council. Two other councils came to much the same conclusion because they had introduced blanket exemptions for firms with 5 or less employees.

It was noted above that only one of the nine councils currently has a party employers' organisation that specifically represents small businesses. It was also mentioned that a number of interviewees believed that small business representation could not be more effective because they did not have the time to organise themselves properly and represent their interests. We asked councils whether they were aware of small business employers' organisations in their sectors, and if there were such organisations, why they had not joined the council.

Five councils were aware of some other employers' organisation(s) organising in their sectors, although one understood that the organisation did not specifically represent small businesses. One council did not know why the employers' organisation in question had not joined the council. Another attributed the organisation's failure to join the council to the perception that the bargaining council was only for big business. Yet another attributed this to the admission thresholds of the council, which were too high, particularly since it is very difficult to organise small businesses. ${ }^{21}$ Significantly, all the interviewees that were aware of some other employers' organisation in their sector believed that these organisations would improve small business representation on the council, notwithstanding their lack of

21 The threshold was keeping at least one employers' organisation that represented small businesses out of the council. 
experience of collective bargaining and the fact that some had acrimonious relations with the existing employer parties.

\subsection{Non-Compliance (i.e. Non-Registration)}

Bargaining council officials were asked to estimate the extent of non-registration by employers within the council's jurisdiction, i.e. the number of firms falling within the council's jurisdiction that were not registered with the council and the number of employees that such firms employed in total. Of the 29 councils, ten did not answer the question. The main reasons appeared to be that the council official felt that they could not even hazard a guess at making such an estimate or that there could not be any unregistered firm because if they knew about such firms then they would go out and register them.

Table 5 sets out the estimates of the 19 councils that did venture an answer regarding the proportion of unregistered employers and employees at unregistered firms - with the estimates provided by councils in the large national and other large council category separated out in columns three and five. 
Table 5: Estimates of Proportion of Unregistered Employers and Employees

\begin{tabular}{|c|c|c|c|c|}
\hline $\begin{array}{l}\text { Unregistered employers or } \\
\text { employees as a proportion of } \\
\text { registered employers or } \\
\text { employees }\end{array}$ & $\begin{array}{l}\text { Number of bargaining } \\
\text { councils: Estimate for } \\
\text { employers }\end{array}$ & $\begin{array}{l}\text { Number of councils in large } \\
\text { national category: Estimate for } \\
\text { employers }\end{array}$ & $\begin{array}{l}\text { Number of bargaining } \\
\text { councils: Estimate for } \\
\text { employees }\end{array}$ & $\begin{array}{l}\text { Number of councils in } \\
\text { large national category: } \\
\text { Estimate for employees }\end{array}$ \\
\hline Less than $5 \%$ & 5 & 2 & 8 & 2 \\
\hline $5 \%$ to $19 \%$ & 4 & 0 & 5 & 1 \\
\hline $20 \%$ to $39 \%$ & 5 & 1 & 4 & 1 \\
\hline $40 \%$ to $99 \%$ & 4 & 1 & 1 & 0 \\
\hline $100 \%$ or more & 1 & 0 & 1 & 0 \\
\hline
\end{tabular}


Five of the 19 councils indicated that the number of unregistered employers amounted to less than 5 per cent of the number of registered employers; and eight councils stated that the number of employees at unregistered firms amounted to less than 5 per cent of all employees with registered firms. Two of the four large national or other large councils fell into this category. For all these councils the level of unregistered employers and employees did not appear to be a significant issue.

For a number of councils the level of non-registration was more of a problem. Ten councils estimated that the proportion of unregistered employers to registered employers was 20 per cent or higher (two of these were large national councils), with one council estimating that there were more unregistered employers than there were registered employers. Six councils estimated that the proportion of employees at unregistered firms compared to total employees at registered firms was 20 per cent or higher (one large national council was in this category). ${ }^{22}$ For those councils that made estimates in the 40 per cent and above range, non-registration has become a major problem and arguably threatens their existence.

A second way in which one might try to measure the number of unregistered firms is to compare the coverage of individual bargaining councils with LFS data for the same sector and area. However, one can do such an exercise for only a few councils. Many councils are excluded because Statistics SA provide data down to only the SIC three-digit level. Most other councils are excluded because their area is defined by magisterial districts whereas the LFS data is based on 52 municipal districts. So one cannot match the area and scope of most councils to an equivalent LFS area and scope in order to compare the bargaining council coverage with the LFS employment data.

Ultimately we were able to do the exercise for only three councils, viz. the clothing bargaining council, the textile bargaining council and the General Goods and Tanning sub-sectors within the leather bargaining council. ${ }^{23}$ These were the only councils that are national (therefore excluding the problem of magisterial districts and municipal districts) and could be matched closely to an SIC sector or sub-sector. But it is probably not an exact match so the comparison should be treated with caution. In fact, the exercise probably does not give one a better estimate than those made by council officials above.

22 The higher number of estimates of non-compliant employers compared to non-compliant employees within each range is indicative of the fact that non-compliant employers are generally small or very small.

23 The councils are not representative: all are national councils, all are in the broadly defined textile, clothing and leather sector, and all are in industries that are under tremendous pressure from imports. 
The clothing bargaining council covered 97958 employees in 2004, of whom 47449 were employed by non-party employers (i.e. they were covered by the extension of the agreement). These are employed in what Statistics SA would define as occupational categories 4 to 9 . The LFS estimate of employment in the clothing industry in these categories is $129417 .{ }^{24}$ If one accepts the LFS estimate then it means that in the clothing industry the bargaining council actually regulates conditions for only 97958 of the 129417 employees in the industry ( 76 per cent), while the remaining 31459 employees (24 per cent) are employed by unregistered employers. ${ }^{25}$

Employer parties on the bargaining council currently represent 52 per cent of the industry if one counts the number of their employees as a proportion of all (registered) employees (i.e. 50509 employees out of 97 958). If one had to take account of the 31459 employees that work for unregistered employers (see above), the representivity of the employer parties would drop to 39 per cent (i.e. the employer parties would employ 50509 of 129417 employees (39 per cent) rather than 50509 of 97958 employees (52 per cent)). In other words, 61 per cent of employees in the industry would be at non-party firms (including unregistered firms) rather than the current 48 per cent. So counting all the employees at unregistered firms would considerably alter the representivity of the council. Not counting them means that the representivity of the council is adequate but there are a large number of employees (and employers) outside the council that undermine the conditions it sets.

The textile bargaining council covered 23876 emloyees in 2004, of whom 4270 were employed by non-party employers. These are employed in occupational categories 8 to 9 (as used by Statistics SA). The LFS estimate of employment in the textile industry in these categories is $43989 .^{26}$ This means that the textile industry bargaining council actually regulates conditions for 54 per cent of employees and the remaining 46 per cent are employed at unregistered employers (again with the proviso that one needs to be cautious with regard to the match of the LFS scope with the scope of the council). ${ }^{27}$

25 This compares to an estimate by the respondent at the council that the number of employees that were employed at unregistered firms amounted to 10 per cent of all employees.

26 SIC codes $311,312,313$ and 336.

27 This compares to an estimate by the respondent at the council that the number of employees that were employed at unregistered firms amounted to 23 per cent of all employees. 
Employer parties on the bargaining council currently represent 82 per cent of the industry if one counts the number of their employees as a proportion of all (registered) employees. If one had to take account of the 20113 employees that work for unregistered employers, the representivity of the employer parties would drop to 46 per cent. In other words, 54 per cent of employees in the industry would be at non-party firms (including unregistered firms) rather than the current 18 per cent.

We could not do the above exercise for the leather bargaining council as a whole because the footwear sector, which is the most important sector, does not yet cover what were the TBVC states. Only the Tanning sector and General Goods sectors cover the entire country. Fortunately, we were able to match these sectors with SIC sectors. ${ }^{28}$ The bargaining council covers 6832 employees in occupational categories 7 to 9 in the tanning and general goods sectors. The LFS employment figure for these occupations in the two sectors is 17353 . This means that the leather industry bargaining council actually regulates conditions for 39 per cent of employees in the tanning and general goods sectors. The remaining 61 per cent are employed at unregistered firms. Again, we caution against using this data as anything more then a rough indicator.

We do not have data on the number of employees at party and non-party firms in the tanning and general goods sectors, so we cannot work out what the impact on representivity would be if unregistered firms were included in the calculation. It would seem, however, that given the number of unregistered employees there would be a quite substantial impact.

Clearly, the above figures, including the estimates made by council officials, must be treated with caution. However, one can at least argue on the basis of the above that the level of non-registration at a number of bargaining councils is significant, and that this poses a threat to those councils. At the very least, taking account of employees at unregistered firms would lower the representivity of many councils.

Of course, the above raises the question of how DoL evaluate the representivity of parties to councils. The LRA sets two quantitative representivity requirements for the extension of agreements. Strictly speaking such requirements should be assessed by calculating representivity with respect to all employees within the jurisdiction of the council (and not just employees at registered firms). Officials of the DoL state that this is indeed the way they 
interpret the requirements. But how does one make such a calculation if one does not know how many employees there are within the jurisdiction of the council?

The answer it seems is with great difficulty and not much accuracy. There are various databases that the DoL can use (the UIF register, the Compensation Commissioners' register, the relevant SETA's database, and Statistics SA's Labour Force Survey) but all define sectors and areas in different ways, none of which necessarily correspond with the way that a bargaining council defines the sector and area it covers. So the DoL makes recourse to such databases but generally they are not found to be very useful. At best they give only a rough guide. The alternative is to get the parties to name non-complying firms and also to rely on objections (to an extension) from other non-party organisations that might indicate numbers of non-complying firms. Such names can then be fed back to the council with the request that they do a verification exercise to establish how many unregistered firms do in fact fall within the jurisdiction of the council and how many employees they employ. ${ }^{29}$ This is a pragmatic way of going about the exercise but is does not come near to solving the problem.

To a certain extent the difficulty of calculating the number of unregistered firms creates an incentive for the parties to councils not to identify unregistered firms. If they do, they reduce their representivity. And where councils do register previously unregistered firms, it is very unlikely that the firm will then join the party employers' organisation, which means that the number of non-party employers and employees will increase and the representivity of the parties will go down. Of course, there is a countervailing incentive for the parties to councils to bring unregistered firms within the ambit of the council, namely to eliminate unfair competition from non-complying firms and to extend the council's employment conditions to the workers in such firms.

It is unknown whether councils act on the incentive to not register unregistered firms. A far more practical explanation for large numbers of unregistered firms is the capacity of councils to undertake the tracking and registration of such firms. In other words, if the council has limited enforcement capacity then this would account for the fact that not much effort is put into finding and registering such firms (or even having a rough idea as to how many unregistered firms there could be). This is discussed in more detail below. 


\subsection{Benefit Funds, Services and Wage Levels}

There are four main ways that councils can make inroads into the level of non-registration. First, the council can seek to enforce its agreements more effectively (see further below). Second, the council can offer a range of benefits and services that would attract firms to register. Third, the council could seek to produce agreements that did not threaten the viability of small and new firms. Or agreements which at least better accommodated the problems faced by small and new firms. This could be by way of lower minimum wages, etc. It could also be by way of a blanket exemption for small and new firms. The latter is discussed further in the section on exemptions below. Finally, a fair and transparent exemption system could also go some way to reducing non-compliance because firms might then choose the option of registering and applying for exemption rather than exempting themselves by not complying. As mentioned above, we discuss exemptions in more detail below.

In the sections that follow we shall discuss the option of benefits and services to attract firms to register as well as, to some extent, the option of lower minimum conditions (focussing on wages).

\subsubsection{Benefit and Other Funds}

Benefit funds have long been a key aspect of bargaining councils. Many of the funds appear to be relatively cheap and are therefore an important attraction for employers and employees to be registered with the council (although they also add to the cost of labour and are therefore seen as onerous by some employers). They can also be used as a way of raising the representivity of the parties, i.e. if the parties allow only their members to join the benefit funds then it is a way of recruiting members and keeping up representivity (although it seems that not many councils have adopted this stratagem). Of course, if the latter route is chosen by a council it probably reduces the incentive of the benefit funds for unregistered employers because in order to access the fund the employer would have to both register with the council and join a party employers' organisation.

Pension/Provident funds were the most prevalent benefit funds administered by councils. Of the 29 councils, 20 had a pension or provident fund or both. Five of the seven large national councils had provident and/or pension funds. The next most prevalent funds were sick pay and sick benefit funds (although it was not always clear from answers whether the council had one or both types). Ten councils had sick benefit funds (i.e. a form of medical aid) while nine had sick pay funds (which provide pay for sick leave). Four of the large national councils had sick pay or sick benefit funds. Generally employers would see such funds as an 
attraction because in the absence of such a fund the employer would be liable for sick pay in terms of the BCEA.

Seven councils had holiday pay funds, which provide for holiday pay over the annual shutdown period (in most cases it seems that the fund also provides for some form of annual bonus). As with sick pay, such funds place much the same obligation on employers as would be imposed on them by the BCEA. However, what such funds do is spread the cost of holiday pay across the year and also guarantee that workers will get their pro rata holiday pay should the employer go out of business. In addition, the holiday fund can provide some sort of annual bonus as well. None of the large national councils had holiday pay funds.

A few councils had other funds. These ranged from funeral funds (four councils) to death benefit funds (although most Pension and Provident funds probably include some form of death benefit) to funds for housing loans (three councils), and unemployment (one council).

In total, the 29 bargaining councils provided for 59 benefit funds. The seven large national councils accounted for 11 funds in total.

Provision of benefit funds are clearly an important function of bargaining councils. They can assist the bargaining council to attract employers and also reduce the burden on the state with regard to health and retirement provision. They are also one way that many small firms can provide such benefits to employees which they would not have been able to do on their own. Councils should therefore be given support with regard to benefit funds. A change to the LRA in 1998 appears to have made things difficult for councils regarding benefit funds. Sections 28(2) and (3) now provide that bargaining council funds must comply with "the provisions of the laws relating to pension, provident or medical aid schemes or funds". It was outside the scope of this study to examine the impact of this change on councils' benefit funds but anecdotal evidence suggests that in many cases councils have struggled to meet this requirement. However, it is an area that requires more research.

\subsubsection{Services Provided by Councils}

Another way that councils can attract firms to register is to provide services to the firms that they find of value. It seems, however, that most councils have been lax in this area. Eleven of the 29 bargaining councils that responded to the questionnaire provided no services at all, including three of the seven large national councils. The most prevalent service was advice to employers regarding labour legislation, the council's agreements, disciplinary procedures, etc. A total of 14 councils provided such a service, although it should be noted that for six councils this was the only service they provided (including one of the large 
national councils). So 17 of the 29 councils either provided no services or were limited to only paralegal-type advice regarding labour law (the 17 councils included four of the seven large national councils).

Only a few councils had expanded the range of services beyond paralegal advice. Some offered various forms of training while others provided information on the industry and topical issues, either through websites or newsletters or information meetings/seminars (or some combination of these). Two councils assisted with disciplinary hearings at firms by chairing such meetings on request, and two councils acted as employment bureaux by keeping a register of the unemployed in the sector and making this available to employers who were seeking to recruit more workers. One council also acted as a conduit for various discounted services, i.e. registered paid-up firms could access certain services at a discount from service providers with which the council had established an arrangement. Another council provided registered firms with brochures that advertised cheaper raw materials.

One council had introduced an important service for businesses, which would be particularly useful for small businesses, although it was not a free service. The council provided full payroll administration, which means that a business could provide the council with its wage records and the council would process the records into wage packets reflecting all the necessary deductions to SARS, UIF, the Compensation Commissioner and, of course, the council itself. The business would get back the wage packets and would have to make up the actual wages and then pay lump sums to SARS, etc. The cost of the service varies according to whether the business paid workers weekly or fortnightly and whether businesses had more than 50 employees or less. But the cost is not high: a business with 50 or less employees would pay a flat rate of R206.50 per week for the service.

It is evident that the notion of councils as a service provider to the industry, beyond its traditional role as a collective bargaining and dispute settlement forum, is not well developed. It is an area where much could be done to make councils a more attractive feature of the industry, providing services that at least in part off-set the cost of compliance for small and micro firms. This is true for the smaller regional and local councils as well as some of the large national councils

One service which most councils now provide in terms of the new LRA is dispute resolution, in the form of either conciliation or conciliation and arbitration. In order to provide this service the council needs to be accredited by the CCMA. In 2004 there were 55 councils accredited 
for conciliation and 35 councils accredited for conciliation and arbitration. ${ }^{30}$ Councils appear to set much store by providing dispute resolution services but these are not without their cost. It is generally agreed that the subsidy paid to councils for the provision of the service is woefully inadequate to cover the actual costs to the council. While this can be partially off-set by using council agents as the conciliators and arbitrators, this option reduces the capacity of the council to enforce its agreements.

\subsubsection{Minimum Wage Levels}

The minimum wage levels set by councils are probably the most difficult aspect of the bargaining council system for small business. We have not examined this issue in great detail as it is complex. However, we sought information from councils with regard to two aspects of wages that indicate an attempt by councils to accommodate different circumstances as well as small businesses. The first was whether there was some form of wage differentiation, i.e. different wage rates for different regions covered by the councils to, for example, provide lower wages for firms in rural areas. The second was the wage rate of the lowest paid job category. We used two sources for this part of the study, namely the questionnaires to councils and the Labour Research Service's database on wage rates (AWARD).

According to the latter database, which provides information on the wages rates of 31 bargaining councils, there are 12 councils that have some form of wage differentiation. The most prevalent type of differentiation is by region. At its simplest this differentiation involves two wage schedules: one for firms in specified urban areas and one for firms in rural or other areas. However, some councils have more sophisticated wage systems. For example, the Electrical Bargaining Council (one of the large national councils) has 12 sets of regional wage rates and the Building Bargaining Council (Southern \& Eastern Cape) has five sets of regional wage rates. The National Bargaining Council for the Clothing Industry (also one of the large national councils), formed out of a merger of a number of regional councils, has an even more sophisticated system of wage differentiation. This differentiates between five main regions, but there is further differentiation within some of these regions on a sub-sectoral basis (i.e. different sets of wage rates for the clothing, knitting and millinery sub-sectors) or on a regional basis (i.e. the Eastern Cape region has five different sets of wage rates for different areas within the region).

30 CCMA Annual Report 2003/2004 at p. 23. It should be noted that the list of councils was compiled prior to the merger of a number of councils to form the National Bargaining Council for the Textile Industry, so the numbers of accredited councils are higher than would be the case at present. 
Some councils such as the Bargaining Council for the Sugar Industry and the Grain Co-operative Bargaining Council, neither of which cover non-parties, have an even more decentralised system of wage schedules. The Sugar Bargaining Council has separate sets of wages for most of the sugar mills that are party to the council. This is also the case for the Grain Co-operative Bargaining Council, which has nine different sets of wages for each of its employer members. Although the actual wage differential is small between the different member firms, it nevertheless shows how flexible centralised bargaining can be.

The questionnaires confirmed the broad pattern indicated by the LRS database (there was considerable overlap between the councils in the LRS database and the councils that completed questionnaires). Of the 29 councils that completed questionnaires, 13 had some form of wage differentiation and one council did not set minimum wages. Of the 13 councils that had wage differentiation, nine differentiated by region. In some cases the differentiation was between only two regions but in other cases the there were different sets of wages for up to six regions. Four councils had some form of sub-sectoral wage differentiation.

As noted above, the differences in the wage rates at the bottom end of the wage schedule were often quite small. Nevertheless, this does show that a large minority of councils are attempting to accommodate differing sectoral and regional circumstances in their agreements. It is arguable that more councils could be doing this. However, there are some councils that have such small jurisdictions in terms of sector and region that it is unnecessary to explore wage differentiation.

According to the Labour Research Service (LRS), in 2004 the monthly income required by a household to maintain a minimum living level (MLL) was R1 946. A higher income level, the supplemented living level (SLL), was R2 549.(Elsley, 2005: 8) These translate into respectively R449.42 and R588.68 per week. The LRS Report provides data on minimum wages for the lowest-paid job category at 30 bargaining councils (in some cases further broken down to take account of the regional or sub-sectoral differentiation).(Labour Research Service, 2005: 42) Only two of the councils had minimum wages above the SLL. In both cases the councils had regional or sectoral differentiation, so not all the minimum wages for each region or sector were above the SLL. At one council (the Leather Bargaining Council) it was at only two sectors/regions out of five that the minimum wages exceeded the SLL. At the other council (the Metal and Engineering Bargaining Council) three of the six sectoral minimum wages exceeded the SLL (and one exceeded the MLL). 
A further nine councils had wages that exceeded the MLL. As with the SLL, four of the nine had some form of differentiation, which meant that not all of the differentiated minimum wages at these councils exceeded the MLL. Minimum wages for the lowest-paid category at the remaining 19 bargaining councils were below the MLL. In some cases the minimum wages rates were substantially below the MLL.

The above is a somewhat cursory examination of minimum wages rates set by bargaining councils and clearly much more work needs to be done to get a clearer picture of this issue. However, the findings indicate quite a clear trend, viz. that in general the rates at the bottom end of bargaining council wage schedules are relatively low. Whether these rates are nevertheless a barrier for small firms or whether it is the rates higher up the wage schedule that are the barrier for small firms requires more detailed research.

\section{Research Findings: Enforcement and Compliance}

\subsection{Bargaining Council Agents (Inspectors) and Inspections}

Councils were asked to state how many agents each had in 2000, 2002 and 2004, and whether they were employed full-time or part-time. As appears from Table 6, the number of agents employed ranged from nil to 39. The biggest numbers of agents employed were at the large national councils, although it should be noted that two of these councils indicated that they had no agents (primarily because they do not have extended agreements and therefore do not have non-parties). The regional and small national councils tended to employ less than 10 agents, and one employed no agents (because it does not extend its agreement). The small local councils employed at most two agents, with two employing only part-time agents and one having no agent. All the other councils employed only full-time agents. 
Table 6(a): Number of Agents, Inspections Per Year and Time Spent Tracing Unregistered Firms: National and/or Large Councils

\begin{tabular}{|l|l|l|l|l|}
\hline Bargaining council & Number of agents in $\mathbf{2 0 0 0}$ & Number of agents in 2004 & $\begin{array}{l}\text { Number of inspections per agent } \\
\text { per year }\end{array}$ & $\begin{array}{l}\text { Proportion of agents' time } \\
\text { tracing unregistered firms }\end{array}$ \\
\hline Chemical & 0 & 0 & 0 & 0 \\
\hline Clothing & 14 & 16 & 780 & 30 \\
\hline Electrical & 4 & 10 & 700 & 20 \\
\hline Metal \& Engineering & 20 & 31 & 46 & 16 \\
\hline Road Freight & 35 & 39 & $\mathrm{~N} / \mathrm{a}$ & Very little \\
\hline SA Road Passenger & 0 & 0 & 0 & 0 \\
\hline Textile & $\mathrm{N} / \mathrm{a}$ & 1 & $\mathrm{~N} / \mathrm{a}$ & 30 \\
\hline
\end{tabular}


Table 6(b): Number of Agents, Inspections Per Year and Time Spent Tracing Unregistered Firms: Regional and Small National Councils

\begin{tabular}{|c|c|c|c|c|}
\hline Bargaining council & $\begin{array}{l}\text { Number of } \\
\text { agents in } 2000\end{array}$ & $\begin{array}{l}\text { Number of } \\
\text { agents in } 2004\end{array}$ & $\begin{array}{l}\text { Number of inspections per } \\
\text { agent per year }\end{array}$ & $\begin{array}{l}\text { Proportion of agents' time } \\
\text { tracing unregistered firms }\end{array}$ \\
\hline Building: Cape & 21 & 13 & 120 & 36 \\
\hline Building: S\&E Cape & 9 & 4 & 900 & 50 \\
\hline Contract Cleaning & 2 & 2 & 950 & 25 \\
\hline Entertainment & 3 & 2 & 60 & 20 \\
\hline Furniture: KZN & 3 & 3 & 169 & 15 \\
\hline Furniture: N Region & 6 & 8 & 70 & 30 \\
\hline Furniture: W Cape & 2 & 4 & 434 & 20 \\
\hline Grain Co-operative & 0 & 0 & 3 & 0 \\
\hline Hairdressing: Semi-Nat. & 3 & 3 & 70 & 35 \\
\hline Meat Trade: Gauteng & 6 & 6 & 15 & 4 \\
\hline Tearoom: Pretoria & 1 & 2 & 1560 & 72 \\
\hline
\end{tabular}


Table 6(c): Number of Agents, Inspections Per Year and Time Spent Tracing Unregistered Firms: Small Regional and Local Councils

\begin{tabular}{|c|c|c|c|c|}
\hline Bargaining council & $\begin{array}{l}\text { Number of agents in } \\
2000\end{array}$ & $\begin{array}{l}\text { Number of agents in } \\
2004\end{array}$ & $\begin{array}{l}\text { Number of inspections per agent } \\
\text { per year }\end{array}$ & $\begin{array}{l}\text { Proportion of agents' time } \\
\text { tracing unregistered firms }\end{array}$ \\
\hline Building: Bloemfontein & 2 & 0 & 104 & $\mathrm{~N} / \mathrm{a}$ \\
\hline Building: Kimberley & 1 & 2 & 1000 & 2 \\
\hline Canvas: Wits \& Pretoria & 1 & 1 & 35 & 5 \\
\hline Diamond Cutting & 1 & 1 & $\mathrm{~N} / \mathrm{a}$ & 10 \\
\hline Furniture: E Cape & 0.5 & 0.5 & 427 & 80 \\
\hline Furniture: SWD & $\mathrm{N} / \mathrm{a}$ & 1 & 15 & 60 \\
\hline Hairdressing: Cape & 1 & 2 & 550 & 10 \\
\hline Hairdressing: Pretoria & $\mathrm{N} / \mathrm{a}$ & 2 & $\mathrm{~N} / \mathrm{a}$ & 0 \\
\hline Jewellery & 1 & 1 & 20 & 20 \\
\hline Laundry: Cape & 1 & 1 & 50 & $\mathrm{~N} / \mathrm{a}$ \\
\hline Laundry: Natal & 0.5 & 0.5 & 70 & 10 \\
\hline
\end{tabular}


Nine councils had increased the number of agents over the period, although in most instances not by much. The exception was the large national council category, where three of the five councils with agents had substantially increased the number of agents over the period (the most significant increase was the Metal and Engineering bargaining council which increased the number of agents by 55 per cent). Four councils had fewer agents in employment in 2004 than in 2002. Fourteen had exactly the same number of agents.

The number of agents a council is able to employ depends to an extent on the number of employees within the jurisdiction of the council in respect of whom contributions are paid. At the same time agents may be required not only to monitor conditions of employment at firms that are registered with the council, but also to track down unregistered firms.

To gauge the capacity of the agents to operate effectively in the sector concerned, and also to put in perspective any changes in the number of agents, we compared the number of agents employed with the total number of employees within the jurisdiction of each council (an alternative way would be to compare the number of agents with the number of firms within the jurisdiction of each council). As might be expected, given the diversity of councils, the ratio of agents to employees within the jurisdiction of each council varied hugely. In the larger national councils there were fewer agents in relation to employees. In the case of the Textile bargaining council, there was only one agent for over 23000 employees in the entire country, although this is probably in part because it is a newly-established council. In the case of the Metal and Engineering bargaining council there was one agent for 8799 employees in 2004, compared with one for 10706 employees in 2002, when the number of inspectors was far fewer, and one for 9813 in 2000, when the number of employees was significantly less. The clothing industry had one agent for 6122 employees, while the council that employs the most agents (road freight) had one agent for every 1836 employees in 2004.

At regional councils the number of agents in relation to employees tended to be less than one per two thousand. Five councils had one full-time agent for less than a thousand employees, while both the councils utilising part-time agents covered less than a thousand employees.

Councils were asked to estimate the average (looking at the past five years) number of inspections done per year by each agent. The responses are recorded in the tables above, and varied from nil to an incredible 1560 inspections a year (in the case of the Tearoom, Restaurant and Catering council). In general, it appeared that smaller, regional or local councils conducted more inspections per agent. The council with the next highest number of inspections per agent per year was also a relatively small local council (the Kimberley 
Building council). On the other hand, larger councils such as the Metal and Engineering bargaining council distinguished between routine inspections and inspections in response to a complaint, and only answered in respect of the former category, presumably because there is no national record of the latter.

The responses regarding the number of inspections conducted should be correlated with the responses to a further question, in which councils were asked to estimate the proportion of an agent's time that is spent on tracking down unregistered firms. As appears from the above tables, some councils spent no time at all on this task, mainly because their agreements were not extended to non-parties. However, many councils whose agreements were extended evidently did not regard this as a key element of the agent's role, and some said agents would only track down unregistered firms if there was a complaint. Eleven out of 27 councils stated that agents spent 10 per cent or less of their time tracking down unregistered firms. There were 21 councils that said agents spent 30 per cent of their time or less doing so. Most of the large national councils that extended their agreements were in the latter category. On the other hand, the four councils that estimated that more than 50 per cent of an agent's time was taken up with unregistered firms were all smaller, regional councils.

\subsection{Compliance Orders}

Councils were asked to specify how many compliance orders were issued in 2000, 2002 and 2004. However, most councils that responded to this question did not have figures for 2000 and 2002 , and only provided data for 2004 . Some did not respond at all, and it was not clear in all instances whether this was because no compliance orders were issued or because the council was unable (or unwilling) to put a figure on it. ${ }^{31}$ The 2004 figures are reflected in Table 7. 
Table 7(a): Enforcement of Agreements: National and/or Large Councils

\begin{tabular}{|l|l|l|l|l|}
\hline Bargaining council & $\begin{array}{l}\text { No. of compliance orders in } \\
\mathbf{2 0 0 4}\end{array}$ & $\begin{array}{l}\text { \% that result in } \\
\text { compliance }\end{array}$ & $\begin{array}{l}\text { No. or arbitration } \\
\text { awards in 2004 }\end{array}$ & $\begin{array}{l}\text { Labour Court orders } \\
\text { in 2004 }\end{array}$ \\
\hline Chemical & 0 & 0 & 0 & 0 \\
\hline Clothing & 1276 & 40 & 1276 & 763 \\
\hline Electrical & 3500 & 50 & 504 & 6 \\
\hline Metal \& Engineering & 2458 & 73 & 336 & 62 \\
\hline Road Freight & 512 & N/a & 658 & 1208 \\
\hline SA Road Passenger & 0 & 0 & 0 & 0 \\
\hline Textile & 14 & 20 & 6 & 0 \\
\hline
\end{tabular}


Table 7(b): Enforcement of Agreements: Regional Councils and Small National Councils

\begin{tabular}{|c|c|c|c|c|}
\hline Bargaining council & $\begin{array}{l}\text { No. of compliance orders in } \\
2004\end{array}$ & $\begin{array}{l}\% \text { that result in } \\
\text { compliance }\end{array}$ & $\begin{array}{l}\text { No. or arbitration } \\
\text { awards in } 2004\end{array}$ & $\begin{array}{l}\text { Labour Court orders } \\
\text { in } 2004\end{array}$ \\
\hline Building: Cape & 194 & 47 & 17 & 26 \\
\hline Building: S\&E Cape & 0 & 60 & 0 & 0 \\
\hline Contract Cleaning & 0 & 50 & 58 & 6 \\
\hline Entertainment & 25 & 90 & 0 & 0 \\
\hline Furniture: KZN & 157 & 46 & 68 & 31 \\
\hline Furniture: N Region & 626 & 85 & 463 & 347 \\
\hline Furniture: W Cape & 298 & Unknown & 92 & 3 \\
\hline Grain Co-operative & 0 & 0 & 0 & 0 \\
\hline Hairdressing: Semi-Nat. & 31 & 95 & 3 & 1 \\
\hline Meat Trade: Gauteng & 20 & 60 & 9 & 2 \\
\hline Tearoom: Pretoria & 180 & 10 & 170 & 31 \\
\hline
\end{tabular}


Table 7(c): Enforcement of Agreements: Small Regional and Local Councils

\begin{tabular}{|c|c|c|c|c|}
\hline Bargaining council & $\begin{array}{l}\text { No. of compliance } \\
\text { orders in } 2004\end{array}$ & $\begin{array}{l}\% \text { that result in } \\
\text { compliance }\end{array}$ & $\begin{array}{l}\text { No. or arbitration } \\
\text { awards in } 2004\end{array}$ & $\begin{array}{l}\text { Labour Court } \\
\text { orders in } 2004\end{array}$ \\
\hline Building: Bloemfontein & 141 & 78 & 9 & 5 \\
\hline Building: Kimberley & 100 & 68 & 32 & 1 \\
\hline Canvas: Wits \& Pretoria & 0 & 0 & 0 & 0 \\
\hline Diamond Cutting & 0 & 0 & 0 & 0 \\
\hline Furniture: E Cape & 4 & 75 & 1 & 0 \\
\hline Furniture: SWD & 9 & 20 & 6 & 0 \\
\hline Hairdressing: Cape & 120 & 80 & 20 & 0 \\
\hline Hairdressing: Pretoria & 1083 & 100 & 101 & 82 \\
\hline Jewellery & 10 & Most & 1 & 0 \\
\hline Laundry: Cape & 0 & 0 & 0 & 0 \\
\hline Laundry: Natal & 19 & 80 & 10 & 1 \\
\hline
\end{tabular}


The table shows that the number of compliance orders issued in 2004 range from nil to 3 500. The largest number of compliance orders were issued by three national councils, i.e. Electrical Industry bargaining council, the Metal and Engineering bargaining council, and the Clothing Industry bargaining council, which is the largest of the councils in terms of employees covered. The first two councils were able to provide data regarding the number of compliance orders issued in 2000 and 2002: 2500 and 2900 in the case of the Electrical Industry council, and 1148 and 1657 in the case of the Metal and Engineering council. This represents respectively an increase of 40 per cent and 114 per cent over the entire period, during which the number of employees covered by the councils increased by some 62 per cent and 39 per cent respectively. In this and similar instances further research would be needed to establish what (if any) significance attaches to this increase.

The Road Freight bargaining council does not utilise compliance orders. Instead it convenes conciliation hearings for all contraventions of agreements and at the end issues a certificate of outcome. Failure by an employer to comply with such a certificate would result in the council proceeding with an arbitration. It is unclear why the number of arbitration awards that were executed as Labour Court orders in 2004 was so much higher than the number of arbitration awards in that year. One explanation would be that the execution of arbitration awards in 2004 included a large number of awards that were made in 2003.

Councils were also asked to estimate what proportion of compliance orders resulted in compliance on the part of the employers. Table 7 shows a wide range of responses, but with most councils indicating that there was generally a quite high level of compliance. As a result, it is not surprising that a relatively small proportion of compliance orders were referred to arbitration, and still fewer were made an order of the Labour Court. The third and fourth columns reflect the actual numbers of such arbitration awards and Labour Court orders in 2004. However, in the case of one council (the Clothing Industry bargaining council) the number of arbitration awards issued in 2004 was 1276 . This corresponds with the number of compliance orders that year. This is presumably indicative of the major problem of non-compliance that has manifested in the clothing sector in the course of 2004 and 2005. The relatively high number of cases resulting in Labour Court orders (763) is also suggestive of this.

There is much in the table that requires further investigation. For example, there were relatively high proportions of arbitrations that resulted in Labour Court orders at the Furniture (Northern Region) council and the Hairdressing (Pretoria) council (bearing in mind that orders granted in 2004 may relate to awards handed down in 2003 or before, due to delays in the legal process). 
Councils were asked to explain what the outcome was with respect to arbitration awards that were not executed as an order of the Labour Court, i.e. did they procure compliance, or were they not executed for other reasons. On the whole councils did not respond to this question satisfactorily. It nevertheless appears that in most instances employers did comply with arbitration awards, albeit after some arm-twisting by the council. Some councils referred to settlement agreements being reached with the employers concerned. These are presumably agreements on terms less favourable than provided in the award. In some instances firms were reported as having closed down, or as having transferred the business to a new owner. In at least two instances councils had granted exemption to such firms subsequent to and notwithstanding the award. 


\section{Research Findings: Exemptions from Bargaining Council Agreements}

An employer may apply for exemption from the provisions of a collective agreement of a bargaining council. It is important to bear in mind that the controversy about the question of exemptions, as noted above, relates to applications by employers who are not parties to the council. However, employer parties also apply for exemptions for a range of reasons. For the purposes of analysis it is necessary to distinguish these two categories, since party applications will almost by definition relate to provisions that are not perceived as core to the agreement in question, such as minimum wages. Party employers, as also noted, tend to be larger firms, whereas non-party employers are more likely to be small or very small (although this is not the case for every council).

\subsection{Structures for Considering Exemptions}

Councils were asked about the structures that determined applications for exemption, and appeals against refusals to grant exemptions. In most cases (19 councils) the committee that considered the initial applications for exemptions was a subcommittee of the council itself. In most cases where councils did not have a sub-committee that heard exemptions it was the full council that did so. However, it appears that at least some councils in fact treated applications by parties and non-parties differently. In the case of one council, for example, the sub-committee heard applications for exemptions by parties to the council while an application by an employer that was not a party to the council was heard by an independent committee. It was not clear what the relationship was between this independent committee and the independent body the council had established to hear appeals.

Seven of the councils (24 per cent) had not established an independent body to hear appeals against the refusal of exemption. As already noted, the establishment of such a body is one of the pre-conditions for the extension of a collective agreement in terms of section 32(3). Councils that did have an independent exemptions committee were asked to give some indication as to credentials or qualifications of the persons on this committee. In most cases the committee was composed of lawyers, CCMA commissioner, ex-trade unionists, academics with industrial relations credentials and in one instance, a person with financial expertise.

Two broad approaches were discernable to the structure of the appeals body, and by implication to the determination of appeals. Some councils clearly endeavoured to structure the committee on bi-partite or tri-partite lines. For example one council emphasised that all persons on the committee should have experience of the industry in which it operated. There was a person with an employer background, a person with a union background and an 
ex-bargaining council agent. Another council had the council composed of 'independent individuals representing commerce/industry, academia and labour.' However, it indicated that the person representing labour on such a committee should not be a trade unionist, presumably meaning a representative of a party trade union.

The implication of structuring the appeals body in this way is that the issue is primarily of a labour relations character. Yet other councils see the body as having a quasi-judicial, or adjudicative role, in which appeals are heard by a single person rather than a committee. One council, for example, had a panel of ombudspersons, one half of whom had been nominated by trade union parties and one half nominated by employer parties. Cases were then heard on a rotational basis, i.e. one case by an employer-nominated ombudsperson, and the next case by a trade union nominated one. In another case the person was appointed on an ad hoc basis from the panel of a dispute resolution body such as Tokiso. Another referred appeals to the CCMA. Two councils relied on the exemption committee (evidently a panel) of the National Association of Bargaining Councils.

In one instance it was a panel composed of an independent arbitrator, with the council's chair and vice-chair as assessors. Given that the chair and vice-chair would have been party or privy to the refusal of exemption, one has to question the independence of such a committee. In the case of a council whose committee is composed of two members of the council's executive committee and a trade union official, it would seem the committee is clearly not independent.

\subsection{Criteria for Exemptions}

Councils were asked what criteria were used in considering applications for exemptions, and whether these criteria were published or not. Only three councils said they had no criteria. One council justified its lack of criteria on the grounds that "no-one asks for exemption - except from the pension [fund]. The others just lie low and hope they are not found." With a few exceptions the councils that had criteria published them in the collective agreement and/or in the council's constitution. A few took additional steps to make these criteria known, such as publication on the council's website. In one of the larger, national councils the criteria are set out in a national exemptions policy. 
An example of the exemptions criteria used by a council (the Textile bargaining council) is as follows:

(a) Whether the granting of the exemption will prejudice the objectives of the bargaining council or contravene the provisions of any labour legislation or collective agreements;

(b) The circumstances prevailing in the textile industry as a whole or the sub-sectors likely to be affected by the application;

(c) The nature and size of the business in respect of which the application is made;

(d) Whether the duration of the exemption is for a limited or specified period;

(e) Any representations made by the employees likely to be affected by the application;

(f) Whether the business plan presented by the applicant demonstrates that the granting of the exemption will make a material difference to the long-term viability of the business in respect of which the exemption is sought;

(g) Whether a refusal to grant an exemption will result in undue financial hardship to the applicant;

(h) Whether the granting of the exemption will undermine collective bargaining and is likely to cause undue financial hardship to the employees affected;

(i) Whether the granting of the exemption will impact negatively on parity agreements; and

(j) Whether the granting of the exemption will impact negatively on local competitors who are complying with collective agreements.

The exemptions criteria for a much smaller council (the Pretoria Hairdressing council) are as follows:

(a) The written and verbal substantiation provided by the applicant;

(b) The extent of consultation with and the petition for or against the granting of the exemption as provided by employers or employees who are to be affected by the exemption if granted;

(c) The terms of the exemption; 
(d) The infringement of basic conditions of employment rights;

(e) The fact that competitive advantage is not created by the exemption;

(f) The views on exemption from any employee benefit fund or training provision in relation to the alternative comparable bona fide benefit or provision, including the cost to the employee, transferability, administration management, and cost, growth and stability;

(g) The extent to which the proposed exemption undermines collective bargaining and labour peace in the Hairdressing and Cosmetology Trade;

(h) Any existing special economic or other circumstances that warrant the granting of the exemption;

(i) Reporting requirements to be met by the applicant, and the monitoring and re-evaluation provisions; and

(j) Cognisance of the recommendations contained in the Report of the Presidential Commission to investigate the Labour Market Policy.

There were four councils that said they had criteria but had not published them. However, these were typically vague, such as 'unfair competition', or 'whether the application will disadvantage other members of the council.' It is also questionable how much regard can be had for criteria that are not published, since they are not known to the applicant. On the other hand, the criteria that have been published comprise eight or more sub-categories which appear to derive from the same precedent and which are, in most instances, not specific to the industry in question. With the exception of criteria that cater for specific kinds of application, such as applications for exemption from an employee benefit fund (where the existence of an alternative comparable benefit is a relevant criterion) there is no indication as to what weighting will be given to the different criteria. Arguably publication is not of great assistance to the potential applicant. 


\subsection{The Procedure for Applying for Exemption}

The overwhelming majority of councils (21 out of 29 ) utilised a standard form for applications for exemption, although this does not necessarily mean that councils would not accept any written application. Almost all the councils also said they allowed an applicant to appear in person before a committee hearing such an application. One only did so on appeal and another only allowed an appearance 'if specifically requested.' Almost all councils also said they contacted the relevant unions and/or employees to get their views on the application, and to object if they so wished. However, this is a question a council was unlikely to answer in the negative, even where it was less than diligent in doing so.

The time taken to process applications for exemption also does not appear unreasonable. Three councils said they took two weeks to do so, but this was clearly not practicable for the majority, and in all cases it would depend on when an application was received. One council said it took between one and four weeks, but the greatest number took four weeks (10 councils), or four to six weeks (3 councils), or four to eight weeks (3 councils). No council said it took longer than eight weeks to process applications.

If the respondents are to be believed, written reasons are always given for the refusal of an application. Only one council said it did not give reasons, although it would if reasons were requested. It was of course not possible within the scope of this survey to consider the adequacy of the reasons given, which no doubt varies considerably from council to council.

\subsection{Conditional Exemptions}

Councils were asked whether exemptions (whether partial and full exemptions) were sometimes granted subject to conditions other than a time limit, and if so what kind of conditions were usually attached to exemptions. Eighteen councils said they did sometimes grant exemptions subject to such conditions, while ten stated that they did not do so.

The types of conditions included the provision for a phase in of the conditions for which the exemption is sought, or some kind of 'catch-up' period ( 3 councils); that proof is provided of the financial situation of the employer, or the benefits it provides ( 3 councils); that provision is made for alternative benefits ( 3 councils); that the employer complies with other 
requirements; or that the implementation of the exemption is monitored. ${ }^{32}$ Five responses to this question were incomprehensible.

\subsection{The Number of Exemptions Granted}

Councils were asked to provide a series of data for the years 2000, 2002 and 2004 regarding exemptions. Table 8 reflects the data provided regarding the number of applications made and granted, split into the three categories of councils. Note that the data is for 17 councils only; these were the councils that provided data for all three years. It is unfortunate that more councils could not provide data for the full period as this would have given a much better indicator of trends over the five years. A number of very large councils provided data only for 2004. Hence the total number of exemption applications in 2004 was 2783.

Table 8(a): Exemption Applications, Granted and Refused: All Councils

\begin{tabular}{|l|l|l|l|}
\hline & $\mathbf{2 0 0 0}$ & $\mathbf{2 0 0 2}$ & $\mathbf{2 0 0 4}$ \\
\hline Total applications made for exemption & 494 & 708 & 649 \\
\hline Total exemptions granted in full & 321 & 432 & 264 \\
\hline Total exemptions partially granted & 22 & 63 & 203 \\
\hline Total exemptions granted subject to conditions & 14 & 28 & 37 \\
\hline Total number of applications refused & 135 & 185 & 145 \\
\hline
\end{tabular}

Table 8(b): Exemption Applications: National and/or Large Councils

\begin{tabular}{|l|l|l|l|}
\hline & $\mathbf{2 0 0 0}$ & $\mathbf{2 0 0 2}$ & $\mathbf{2 0 0 4}$ \\
\hline Total applications made for exemption & 291 & 487 & 319 \\
\hline Total exemptions granted in full & 220 & 331 & 151 \\
\hline Total exemptions partially granted & 8 & 23 & 38 \\
\hline Total exemptions granted subject to conditions & 8 & 18 & 25 \\
\hline Total number of applications refused & 55 & 115 & 105 \\
\hline
\end{tabular}

32 It is not clear that these are all conditions. The first instance appears to be a variation on a time limit whereas some of the others appear to be requirements of the exemption application rather than conditions. 
Table 8(c): Exemption Applications: Regional Councils and Small National Councils

\begin{tabular}{|l|l|l|l|}
\hline & $\mathbf{2 0 0 0}$ & $\mathbf{2 0 0 2}$ & $\mathbf{2 0 0 4}$ \\
\hline Total applications made for exemption & 149 & 154 & 236 \\
\hline Total exemptions granted in full & 60 & 49 & 38 \\
\hline Total exemptions partially granted & 11 & 37 & 163 \\
\hline Total exemptions granted subject to conditions & 6 & 9 & 10 \\
\hline Total number of applications refused & 72 & 59 & 25 \\
\hline
\end{tabular}

Table 8(d): Exemption Applications: Small Regional and Local Councils ${ }^{33}$

\begin{tabular}{|l|l|l|l|}
\hline & $\mathbf{2 0 0 0}$ & $\mathbf{2 0 0 2}$ & $\mathbf{2 0 0 4}$ \\
\hline Total applications made for exemption & 54 & 67 & 94 \\
\hline Total exemptions granted in full & 41 & 52 & 75 \\
\hline Total exemptions partially granted & 3 & 3 & 2 \\
\hline Total exemptions granted subject to conditions & 0 & 1 & 2 \\
\hline Total number of applications refused & 8 & 11 & 15 \\
\hline
\end{tabular}

Table 8 (a) shows that there was a quite dramatic increase in the number of applications for exemptions between 2000 and 2002 (43 per cent), and then a bit of a fall-off in 2004 (although this figure is still 31 per cent up on the 2000 figure). The proportion of exemptions granted in full in 2000 was 65 per cent, and if one includes partial and conditional exemptions this proportion rose to 72 per cent. In 2002 the equivalent proportions were 61 per cent granted in full and 74 per cent when one includes the partial and conditional exemptions. In 2004 the proportions were 41 per cent and 78 per cent. The overall proportion of exemptions granted therefore remained fairly constant in the 70 per cent range, but there was an increasing number of partial exemptions as against full exemptions. This was primarily the result of a very big increase in partial exemptions granted by the Furniture (Greater Northern Region) bargaining council. ${ }^{34}$

33 Note that the figures for 2000 do not add up to the total number of applications made. This is probably because some applications were withdrawn.

34 The increase appears to have been generated by the introduction of a new benefit fund, which resulted in a big rise in exemption applications, and presumably an increase in exemptions that were granted subject to an alternative fund offering equivalent or better benefits. 
When one disaggregates the data into the three categories of council one finds quite different trends emerging. The large national council category shows a sharp increase in applications in 2002 (up by 67 per cent) and then a dip in 2004 (up by 10 per cent on the 2000 figure). The Road Freight council, in particular, contributed to the increase in applications, in part because of the increase in the number of employees covered by the council over the period. The success rate of applications to the large national councils, however, showed a steady decline over the period. In 200076 per cent of all applications were granted in full, but this dropped to 68 per cent in 2002 and to 47 per cent in 2004. When one adds in the partially granted and conditional exemptions, the success rate also shows a decline: from a high 81 per cent in 2000, to 76 per cent in 2002, to 67 per cent in 2004.

There is a different pattern in the regional and small national council category. In this category the number of applications increases slightly between 2000 and 2002 by 3 per cent, and then rises sharply in 2004 (up 58 per cent on the 2000 figure). As with the national council category, one council - Furniture (Northern Region) - accounted for a significant part of the increase. The success rate of applications granted in full was much lower than overall rate: 40 per cent in 2000, 32 per cent in 2002, and 16 per cent in 2004. However, this changes dramatically when one includes the partially granted exemptions and conditional exemptions, mainly because of the influence of the data for the Furniture (Northern Region) council: 52 per cent in 2000, 62 per cent in 2002, and 89 per cent in 2004. This is, as noted above, mainly because of the increase number of applications and partially granted exemptions that followed the introduction of a new benefit fund by the council.

The small regional and local council category shows an increase in the number of exemption applications, ending 74 per cent up on the 2000 total. In this case the success rate of applications is high and almost constant, both for the exemptions granted in full (starting at 76 per cent and ending at 80 per cent) and when one includes the partially granted exemptions and conditional exemptions (82 per cent in 2000 and 84 per cent in 2004).

It should be emphasised that the above data is for 17 councils only, i.e. the councils that submitted data for the entire period. Twenty-four councils submitted data for 2004. Examining this data shows that of the 2783 applications made, 2037 were granted full exemption, 208 were partially granted, 40 were granted subject to conditions, and 425 were refused. This gives an even better success rate than for the councils that provided data for all three years: 73 per cent of applications were granted in full and 82 per cent were granted in full or partially or subject to conditions. 


\subsection{The Number of Appeals}

Councils were asked to provide the following data in respect of appeals against exemption refusals by year for the years 2000, 2002 and 2004. Note that only 16 councils provided data for all three years (not all the same as the above 17 councils). Table 9 focuses on the data provided by the 16 councils.

Table 9: Appeals against the Refusal of Exemption Applications

\begin{tabular}{|l|l|l|l|}
\hline & 2000 & 2002 & 2004 \\
\hline $\begin{array}{l}\text { Total number of appeals against the refusal of an } \\
\text { exemption application }\end{array}$ & 35 & 33 & 76 \\
\hline Total exemptions granted in full on appeal & 4 & 8 & 9 \\
\hline $\begin{array}{l}\text { Total exemptions granted partially or subject to } \\
\text { conditions on appeal }\end{array}$ & 9 & 10 & 55 \\
\hline Total number of appeals refused & 22 & 15 & 12 \\
\hline
\end{tabular}

The data suggests that only a small proportion of refused exemptions are taken on appeal. The 17 councils analysed in Tables 8 (a) to (d) above overlap to a large extent with the 16 councils analysed in respect of appeals. When comparing the data for the two sets of councils one finds that only about 16 per cent of refusals were taken on appeal in 2000, and that this declined to about 8 per cent in 2002 and 2004.

The data indicates an overall increase in the number of appeals, although this increase is primarily the result of appeals at one council jumping significantly (i.e. the Furniture (Northern Region) bargaining council). The reasons for the increase at the latter council are almost certainly linked to the introduction of the new benefit scheme discussed above. This also accounts for the jump in the number of partially granted exemptions on appeal.

Refusals of exemptions on appeal make up a relatively large proportion of appeals in 2000 and 2002, respectively 63 per cent and 45 per cent. But in 2004 refusals on appeal declined dramatically, primarily as a result of the Furniture (Northern Region) council granting a large number of partial exemptions on appeal. The proportion of refused exemptions in 2004 was 16 per cent. However, if one looks at all the data received for 2004 (i.e. 22 councils provided data for 2004) the refusal rate climbs to 33 per cent (of a total of 115 appeals). 


\subsection{The Number of Employees Covered by Exemptions}

Councils were also asked to indicate how many employees were covered by the (full and partial) exemptions granted each year in 2000, 2002 and 2004. Only 14 councils provided data for the three years. The results are in Table 10, split into the three categories of councils:

Table 10: Number of Employees Covered by Exemptions

\begin{tabular}{|l|l|l|l|}
\hline Category of bargaining council & $\mathbf{2 0 0 0}$ & $\mathbf{2 0 0 2}$ & $\mathbf{2 0 0 4}$ \\
\hline National and/or large councils (2 councils) & 756 & 1969 & 2500 \\
\hline Regional \& small national councils (5 councils) & 228 & 328 & 1459 \\
\hline Small regional \& local councils (7 councils) & 144 & 583 & 286 \\
\hline TOTAL (14 councils) & 1128 & 2880 & 4245 \\
\hline
\end{tabular}

The data indicates a surprisingly low number of employees covered by exemptions, although there is a steep increase in the number of employees over the period. The low number of employees compared to the number of exemptions granted strongly suggests that the majority of exemptions are for small firms.

As one would expect, most employees covered by exemptions fall under the large national councils. This category shows an increase in employees over the period in line with the overall data. The same trend emerges in the regional and small national council category. The small regional and local council category shows a different trend, with a peak in 2002

Again, it is unfortunate that more councils could not provide data for all three years as this would have given a clearer indication of trends. Twenty-one councils provided data for 2004 , which indicated that the total number of employees covered by exemptions in that year was 30817 , mainly because of the inclusion of 22681 employees covered by exemptions from the Clothing Industry bargaining council. ${ }^{35}$ 


\subsection{The Number of Exemptions Granted to Small Business}

It follows from what has been said above that it is important to know how many applications for exemptions are from small business, and it is therefore necessary to know how a 'small business' is defined by councils. Councils were asked whether they had a definition of small, medium and large firms. Sixteen councils said they had and thirteen did not.

Not surprisingly, given that they operate in different industries that each have their own structures and distribution of firm sizes, the definitions of small, medium and large firms varies enormously between councils. The overwhelming majority of councils (13 out of 16) define small firms as employing less than 10 employees. However, one (Contract Cleaning) defines small firms as employing less than 50 while one (SA Road Passenger) defines small firm as having less than 100 employees. By way of contrast, the Road Freight council defines a small firm as one employing up to 2 drivers.

At the other extreme there are two councils that view large firms as ones employing more than 10 employees. These are Hairdressing (Cape Peninsula) and Building (Cape). But the largest number of councils ( 5 out of 9 ) give definitions for large firms as employing more than 50 employees. That means councils most commonly view medium firms to range between 10 and 50 employees.

Councils were asked to break down the applications made in 2000, 2002 and 2004 by size of firms, i.e. small, medium and large. A total of 14 councils provided data for all three years. This is displayed in Table 11, firstly in total and then split into the three different categories of councils. 
Table 11: Exemption Applications by Types of Councils and Size of Firm

\begin{tabular}{|c|c|c|c|c|}
\hline & & 2000 & 2002 & 2004 \\
\hline \multirow[t]{3}{*}{ All councils (14 councils): } & Small firms & 229 & 422 & 397 \\
\hline & Medium-sized firms & 106 & 49 & 42 \\
\hline & Large firms & 197 & 172 & 154 \\
\hline \multirow[t]{3}{*}{ Small regional and local councils (7 councils): } & Small firms & 45 & 47 & 80 \\
\hline & Medium-sized firms & 11 & 20 & 16 \\
\hline & Large firms & 2 & 4 & 0 \\
\hline \multirow[t]{3}{*}{ Regional and small national councils ( 6 councils): } & Small firms & 105 & 107 & 192 \\
\hline & Medium-sized firms & 95 & 29 & 26 \\
\hline & Large firms & 4 & 3 & 7 \\
\hline \multirow[t]{3}{*}{ National and/or large councils (1 council): } & Small firms & 79 & 268 & 125 \\
\hline & Medium-sized firms & 0 & 0 & 0 \\
\hline & Large firms & 191 & 165 & 147 \\
\hline
\end{tabular}


The above data indicates that the largest proportion of applications for exemption for the 14 councils were from small firms, as defined by the council concerned (43 per cent in 2000; 66 per cent in 2002; and, 67 per cent in 2004). Furthermore, the applications from small firms increased over the period, although the 2004 figure is somewhat down on the 2002 figure. Applications from medium-sized and large firms, on the other hand, declined over the five years.

Unfortunately, only one of the large national councils provided data for the entire period (i.e. the Road Freight council). The council accounts for almost all the applications from large firms (191, 165 and 147 in the three years), most probably because of the way the council defines small, medium and large firms. The council also accounts for a large proportion of the applications from small firms, with the trend following the overall pattern of a sharp rise in 2002 and then a dip to 2004.

Few large firms make application to councils in the regional and small national council category and the small regional and local council category. Applications to councils in the former category are mainly from medium-sized and small firms, and applications to the latter category are mainly from small firms. This reflects the size of firms that tend to be covered by the councils in these categories. In both categories exemption applications from small firms increase marginally between 2000 and 2002, and then increase significantly in 2004.

Twenty councils submitted data for 2004. Analysis of this data shows that 1564 applications were made to the councils in that year, of which 42 per cent came from small firms. Almost the same number of applications came from medium-sized firms, mainly because of a very large number of applications to the Metal and Engineering bargaining council. This suggests that if more councils had provided data for all three years the findings could have been quite different.

Councils were then asked how many applications from small firms were refused. The responses of the 13 councils that provided data for both applications from small firms for all three years and number of applications from small firms refused for the three years are recorded in Table 12, split into total applications, all applications from small firms refused, and refusals of small firms applications by category of council. 
Table 12: The Number of Refused Exemption Applications from Small Firms

\begin{tabular}{|l|l|l|l|}
\hline & 2000 & 2002 & 2004 \\
\hline Total applications from small firms (13 councils) & 211 & 397 & 367 \\
\hline $\begin{array}{l}\text { Applications from small firms refused by national and/or large councils } \\
(1 \text { council) }\end{array}$ & 21 & 63 & 13 \\
\hline $\begin{array}{l}\text { Applications from small firms refused by regional and small national } \\
\text { councils (6 councils) }\end{array}$ & 21 & 20 & 21 \\
\hline $\begin{array}{l}\text { Applications from small firms refused by regional and small national } \\
\text { councils (6 councils) }\end{array}$ & 6 & 3 & 4 \\
\hline Applications from small firms refused by all councils (13 councils) & 48 & 86 & 38 \\
\hline
\end{tabular}

In Table 8 (a), which dealt with all exemption applications, the refusal rate was 27 per cent in 2000,26 per cent in 2002, and 22 per cent in 2004. Table 12 shows that the refusal rate for applications from small firms was lower across the period and was also declining: 23 per cent of applications from small firms were refused in 2000; 22 per cent were refused in 2002; and, 10 per cent were refused in 2004. Further research would be needed to establish why the rate for small firms is lower than that for all firms.

The refusal rate for applications from small firms at the national and/or other large council category was 27 per cent, 24 per cent and 10 per cent across the three years. The rate therefore starts higher than the rate for all small firms but ends on the same proportion in 2004.

The refusal rate for exemption applications from small firms at the other two categories of council was lower than the overall rate and that for national councils. The rate in the regional and small national councils category was 20 per cent, 19 per cent and 11 per cent across the three years, while the rate in the small regional and local councils category was 22 per cent, 9 per cent and 8 per cent over the period. 
Data supplied by the DoL in respect of 44 bargaining councils shows that in 2003 there were 7373 applications for exemption, of which 4344 were from small firms, i.e. 59 per cent (which is fairly close to the rate established by our survey for 2002 and 2004). ${ }^{36}$ The total number of applications granted was 5 670, i.e. 77 per cent. Of the 4344 applications from small firms, 3407 were granted, i.e. 78 per cent. The success rate of small firm applications was therefore fractionally higher than the rate for all applications.

The overall success rate according to the DoL data was therefore almost the same as the 2004 rate established by our survey, assuming that the DoL is including partial and conditional exemptions in its figures for granted applications. The slightly higher success rate for applications from small firms is also replicated in the survey data, although in 2004 the survey data indicates a sharp increase in the success rate.

In 2004 DoL reported on data from 37 councils. A total of 5719 exemption applications were made to the councils in the year, of which 1380 were from small firms, i.e. 24 per cent. It is unclear why there was such a large drop in applications from small firms. Of the 5719 applications for exemption, 4648 were granted (81 per cent), a success rate that is almost the same as the rate the survey found when analysing all the data for 2004 (i.e. 82 per cent).

Of the 1380 applications from small firms, 1050 were granted (76 per cent). Although there was a sharp reduction in the number of applications from small firms in 2004, the success rate remained much the same as in 2003. It should be noted, furthermore, that at the end of 2004, 171 of the above exemption applications (3 per cent) were still under consideration, of which 38 were from small firms ( 3 per cent). So the success rate would almost certainly be higher once these applications have been finalised (and possibly would have ended much closer to the higher success rate for 2004 found in the survey). 


\subsection{The Number of Non-Party Applications}

Councils were asked to break down the applications made in 2000, 2002 and 2004 by party and non-party applications, by first-time applications and 'repeat' applications, ${ }^{37}$ by size of firm, and by the type of application. Table 13 displays the results. Note that only councils that provided data for all three years in each category are included. This was the case for 11 councils with respect to party/non-party applications, 12 councils for first-time and repeat applications, and 12 for the type of request.

Table 13: Exemption Applications by Type of Application

\begin{tabular}{|l|l|l|l|l|}
\hline & & $\mathbf{2 0 0 0}$ & $\mathbf{2 0 0 2}$ & $\mathbf{2 0 0 4}$ \\
\hline \multirow{2}{*}{$\begin{array}{l}\text { Number of party as opposed to } \\
\text { non-party applications: }\end{array}$} & Party & 38 & 39 & 39 \\
\cline { 2 - 5 } & Non-party & 131 & 155 & 269 \\
\hline \multirow{2}{*}{$\begin{array}{l}\text { Number of first-time applications as } \\
\text { opposed to 'repeat' applications: }\end{array}$} & First-time & 157 & 163 & 270 \\
\cline { 2 - 5 } & 'Repeats' & 13 & 30 & 39 \\
\hline \multirow{3}{*}{$\begin{array}{l}\text { Number of applicationsby type of request, } \\
\text { i.e. exemption from: }\end{array}$} & $\begin{array}{l}\text { Entire main } \\
\text { agreement }\end{array}$ & 10 & 11 & 8 \\
\cline { 2 - 5 } & Wage clause only & 44 & 52 & 40 \\
\cline { 2 - 5 } & Benefit funds & 56 & 101 & 263 \\
\cline { 2 - 5 } & Other & 63 & 56 & 11 \\
\hline
\end{tabular}

The most significant of the above figures is the comparison between party and non-party applications, since the controversy about exemptions has essentially been about non-party applications. What the above data tells us is that in all three years the vast majority of applications at the 11 bargaining councils was from non-parties (it ranged from 78 per cent to 87 per cent across the period). If one just looks at data for 2004 (20 councils provided data for 2004), there were 948 applications from non-parties (65 per cent) as opposed to 507 applications from parties (35 per cent). The higher proportion of applications from parties is

37 A 'repeat' application is where an exemption was granted subject to a time limit, so it is re-applied for again (and again) at the end of each period. 
largely accounted by high numbers for the Furniture (Western Cape) council, the Meat Trade (Gauteng) council, and the Metal and Engineering council.

Unfortunately, none of the 11 councils that provided data on applications from parties and non-parties was in the national and/or other large council category. Examining the data broken down by the remaining two categories, one finds that the number of applications from non-parties increases across the three years for councils in both the regional and small national category and the small regional and local category (although the increase in the former category is significantly steeper). However, the data on party applications reveals different trends. In this case the applications from small regional and local councils steadily increases across the period, whereas there is a steady decline in applications from parties at councils in the regional and small national category. It is unclear why this is so or whether it is significant.

Table 13 also makes it evident that 'repeat' applications do not constitute a large proportion of all exemption applications. Generally exemption applications are applied for on a first-time basis.

It is perhaps not surprising that there were relatively few applications for exemption from the entire agreement, because most firms not wanting to comply with the agreements at all are unlikely to apply for an exemption. Instead, they would probably not register with the council. It is nevertheless interesting that there is a quite high number of applications in respect of the wage clause. It would probably be safe to assume these are all applications by non-parties. The largest proportion of applications, however, came in respect of council benefit funds. Further research would be required to establish for which type of funds exemptions were sought and whether this was because the firm had an alternative in place or was simply unable to meet the cost of benefit fund contributions.

Twenty-one councils submitted data only for 2004. This shows a quite significant difference to the data submitted by the 12 councils across the entire period, mainly because of the impact of the Metal and Engineering bargaining council data. There were still few applications for exemption from the entire agreement (14), but a much higher proportion of applications were from the wage clause (513 applications). Applications for exemption from the benefit funds were high (491), but there was a big jump in the number of 'other' exemptions (448). 
Councils were asked to estimate what proportion of refused applications was from non-parties in the period 2000-2004. The average proportion across the 17 councils that provided an estimate was 33 per cent, but it should be noted that there was a wide range of responses. Seven of the 17 councils stated that none of the applications from non-parties had been refused, while one council indicated that all refused applications had come from non-parties. Three councils estimated that over 85 per cent of refused applications were from non-parties. The average of 33 per cent is somewhat higher than the refusal rate for all applications (see above) and is significantly higher than the refusal rate for small firms.

Five of the large national councils provided estimates. In two cases the councils indicated that none of the refused applications was from non-parties (in one case because the agreement is not extended). However, the remaining three councils (Chemical, Textile, and Metal and Engineering) all estimate that 50 per cent or more of refused applications was from non-parties.

\subsection{Previously Unregistered Firms that Apply for Exemption}

We also sought to establish to what extent exemption applications were generated by councils' inspectors locating previously unregistered firms that when compelled to register did so simultaneously with an application for exemption. Councils were therefore asked to estimate the proportion of exemptions from previously unregistered firms that had been 'caught' and had registered but simultaneously applied for exemption.

Nineteen councils provided an estimate. The average of the estimate across the 19 councils was 20 per cent, but it must be noted that there was a wide range of responses. Thirteen councils indicated that less than 5 per cent of applications were from such 'caught' firms. But a few councils estimated that 80 per cent to 90 per cent of applications were generated in this way. None of the large national councils were in the latter category.

\subsection{Blanket Exemptions}

Councils were asked whether any category of business was granted an automatic (or blanket) exemption. A blanket exemption is where a business is exempted from a collective agreement simply by virtue of belonging to the relevant category without the necessity of formally applying for exemption, although this does not necessarily mean a business is not required to register with the council. 
Ten councils (out of 27) stated that they did provide for blanket exemptions. Of these, six granted blanket exemptions to small enterprises employing less than five people or one-person or owner-driver (in the case of Road Freight) or owner-builder operations (in the case of Building). Four councils did not base their categorisation on the size of the business but rather the type of business. The categories exempted were Afro hairdressing (in respect of salaries), low-cost home builders in 'Black' areas, laundromats, and gate \& fence manufacturers (in the case of Metal and Engineering). Three of the 10 councils that provided for blanket exemptions were in the national and/or other large council category.

Only two councils did not require such businesses to register first with the council to qualify for the exemption. ${ }^{38}$ Thus in the majority of cases the business had to first register with the council to qualify for the exemption.

Where there was an automatic (or blanket) exemption, councils were asked to provide the following data for the years 2000, 2002 and 2004, or to estimate the number of employers and employees covered by the blanket exemption. Only four of the ten councils provided data for all three years. The data is presented in Table 14.

\section{Table 14: Number of Firms and Employees Covered by Blanket Exemptions}

\begin{tabular}{|l|l|l|l|}
\hline & 2000 & 2002 & 2004 \\
\hline $\begin{array}{l}\text { Total number of firms covered by automatic (or blanket) } \\
\text { exemption }\end{array}$ & 265 & 206 & 175 \\
\hline $\begin{array}{l}\text { Total number of employees at the firms covered by } \\
\text { automatic exemptions }\end{array}$ & 553 & 549 & 573 \\
\hline
\end{tabular}

Even though the above data is for four councils only, it is apparent that blanket exemptions do not cover a very large number of employees but do cover quite a large number of firms or operations (obviously because of the size categories used for most blanket exemptions). As confirmation of this, total coverage of blanket exemptions for seven councils in 2004 was 527 firms and 2607 employees.

38 These were the Cape Building bargaining council which has a blanket exemption for owner-builders and the Pretoria Hairdressing council which has a blanket exemption for the Afro hairdressing sector (in respect of salaries). 


\subsection{Other Provisions 'friendly' to Small Business}

Councils were asked whether there were any other provisions besides a blanket exemption in the council's agreements that could be seen as in some way accommodating small businesses (or other categories of business). Eight (out of 28) councils said there were, while some indicated that this was not necessary as almost all firms in the industry were small. The small business 'friendly' provisions can be categorised as follows: three councils indicated wage concessions on a regional or sub-sectoral basis (i.e. the Afro hairdressing sector); two councils made certain concessions in respect of the overtime rate and limit; two councils stated that certain provisions were relaxed for workers starting in the industry (for a stipulated period); and two councils had some form of phasing in of firms (one for firms in former TBVC states that has now expired, one for the plastics sub-sector; one for enterprises operating in depressed areas such as Botshabelo; and one for Afro hairdressing). It should be noted that some councils had more than one such provision for small firms. It should also be noted that some of the provisions did not appear to be specific to small firms. 


\section{Part C: The BCEA and Sectoral Determinations}

\section{The Basic Conditions of Employment Act (BCEA)}

The BCEA applies to all employees in South Africa, excluding only employees of the SA Defence Force and the two secret service agencies. The Act provides a floor of minimum employment conditions with which all employment contracts must comply. The conditions regulated by the Act range from maximum hours of work, limits on overtime, the rate of overtime pay, annual leave, sick leave, maternity leave, family responsibility leave, notice periods, and records to be kept by employers. The Act also sets up the Employment Conditions Commission (ECC) which has certain advisory and reporting functions. Importantly, the Act provides for a number of methods through which conditions can be varied. These range from a limited set of conditions that can be varied by individual agreement, a more extensive set of conditions that can be varied by collective agreement, and another set that can be varied by a bargaining council agreement, a set of conditions that can be varied by the Minister of Labour through a ministerial determination, and a set of conditions that can be varied by a sectoral determination. The Act does not set a minimum wage but minimum wages are introduced to sectors through sectoral determinations.

Negotiations in NEDLAC over the Act were adversarial and difficult. The Bill was eventually referred to Parliament by the Minister of Labour on the basis that 'sufficient consensus' had been reached. But part of the agreement in this regard was that the Act would not be promulgated until an impact assessment study had been done on its likely impact on small business. This study was done and concluded that overall the Act would not have a major impact on small business but some conditions would impact negatively on firms in some sectors. As a result of the study a ministerial determination was produced that relaxed four of the conditions in the Act for businesses employing less than 10 employees.

The BCEA is supposedly the most complete statement of the government's concept of 'regulated flexibility'. While, compared to the 1983 Act, it extended coverage, added new conditions and improved certain conditions, it also provided that conditions could be varied in certain ways. The Minister is able to vary conditions through sectoral determinations and ministerial determinations, bargaining councils are able to vary conditions, unions and employers can negotiate the variation of some conditions, and certain conditions can be varied by individual agreements. However, all variation must be in terms of the Act, which in each case specifies the conditions that can be varied in the above ways. The result is that there is a set of 'core' conditions that cannot be varied at all. 


\subsection{Sectoral Determinations}

In order to make a sectoral determination establishing basic conditions in a sector and area the DoL first conducts an investigation of the conditions of employment in the sector concerned (ss 52 and 53 of the BCEA deal with the procedure to be followed in conducting the investigation). Following the investigation a report is prepared, which is submitted to the Employment Conditions Commission (ECC). The ECC examines the report and advises the Minister regarding the appropriateness of a sectoral determination taking into the account a number of factors, including "the operation of small, medium and micro-enterprises, and new enterprises" (s 54). The ECC advises the Minister by way of its own report in which it makes recommendations regarding matters which should be included in the sectoral determination. The Minister can refer certain matters with which he/she disagrees back to the ECC for reconsideration.

A sectoral determination can deal with a wide range of minimum terms and conditions of employment, but probably the most important is that it can introduce minimum wages for the relevant sector and area. The range of conditions that a sectoral determination can cover give wide scope for the variation of conditions in the Act for the circumstances of a particular sector and area. But, as noted above, the Act specifies a number of conditions that a sectoral determination is not allowed to vary. Once the sectoral determination has legal effect its provisions prevail over an equivalent provision in the BCEA.

\subsection{Ministerial Determinations}

The Minister is also able to vary conditions of employment by what are called ministerial determinations. There are two types of ministerial determination. The first applies to "any category of employees or category of employers" (s 50). Such a determination is made on the advice of the ECC and is published in the Government Gazette. These ministerial determinations are similar in many respects to sectoral determinations. They cover a particular sector and area, deal with and vary a wide range of employment conditions, and are restricted from varying certain conditions. The main difference in practice is that the ministerial determinations have not introduced minimum wages.

The second type of ministerial determination is made as a result of an application by an employer and/or registered employers' organisation. In effect it is an application for an exemption from one or other of the Act's provisions (excluding specified conditions). The Minister can ask the ECC to advise on such an application and may also request it to prepare guidelines for the consideration of such applications. A condition for the issue of such a 
determination is that the application must have the consent of every registered trade union that represents employees in respect of whom the determination is to apply. However, a determination may still be made if consent has not been obtained, if the application has been served on any registered trade union representing employees to which it would apply or, if there is no registered trade union, efforts have been made to bring the application to the attention of the employees.

Such a determination can be issued subject to conditions and for a period determined by the Minister. The Minister can also on application by any affected party amend or withdraw the determination.

\subsection{Enforcement}

The inspectorate of the DoL is responsible for the policing and enforcement of the BCEA and all determinations issued in terms of the Act (ss 64 to 66 deal with the functions and powers of inspectors). As with the LRA, the BCEA decriminalised non-compliance and introduced a new enforcement procedure. The new procedure starts with the inspector attempting to secure a written undertaking from a non-complying employer in which the employer undertakes to comply with the Act. The undertaking can also deal with the payments owing to employees as a result of the non-compliance. The next step in the procedure is the issue of a compliance order, which the inspector serves on the relevant employer(s). The compliance order must set out the provisions that have not been complied with, any amounts the employer is required to pay, the steps the employer must take to rectify the non-compliance, and the fine that may be imposed if the employer fails to comply.

Thereafter the employer can object to the compliance order to the Director-General (DG). The DG can confirm, modify or cancel a compliance order or any part of an order. The employer can then appeal to the Labour Court from the decision of the DG. The order is suspended pending the final determination of the appeal by the Labour Court. The DG may also apply to the Labour Court for a compliance order to be made an order of the Labour Court.

There are no requirements in the Act for employers, employers' organisations or trade unions to submit data to the DoL. The one area in which the DoL does gather data is with regard to the investigations conducted pursuant to a sectoral determination. It is assumed that the ECC also gathers data in order to perform its various advisory functions. Of course, one would also expect the Department to be recording data on its own enforcements efforts, i.e. number of inspectors, number of inspections, number of compliance orders, and related matters. There does not, however, appear to be any attempt within the DoL to gather data on 
an on-going basis regarding the coverage of the various sectoral and ministerial determinations.

The same comments made above regarding the bargaining council data apply in the case of data on the BCEA. What data is collected is not made easily available to the public.

\section{Research Findings: The BCEA and Sectoral Determinations}

\subsection{Coverage of the BCEA and Sectoral Determinations}

The BCEA covers approximately 7.15 million employees. ${ }^{39}$ It must be noted, however, that major sections of the Act do not apply to people employed at the same employer for less than 24 hours per month, senior managerial employees and employees earning over R115 572 (the latter threshold is determined by the Minister and changes from time to time).

As noted above, sectoral and ministerial determinations are published by the Minister in terms of the Act. Both provide for variations on the Act's provisions but sectoral determinations are also used to introduce minimum wages for sectors. Approximately 3.5 million workers are covered by sectoral determinations. To date the following sectoral determinations have been published, together with the coverage of employers and employees for each (note that the dates of the data vary according to when the investigation for the sectoral determination was conducted). ${ }^{40}$

39 This is the total number of employees as per the September 2004 LFS, minus employment in the SANDF and minus the 2358012 employees covered by bargaining councils.

40 Note that the Sectoral Determination for the Clothing and Knitting Sector was effectively replaced by the National Bargaining Council for the Clothing Industry's collective agreement for non-metropolitan areas. It was subsequently withdrawn. 
Table 15: Coverage of Sectoral Determinations: Employers and Employees

\begin{tabular}{|l|l|l|}
\hline \multicolumn{1}{|c|}{ Sectoral determination } & Number of employers & Number of employees \\
\hline Agriculture & 65000 & 850000 \\
\hline Domestic & 850000 & 1000000 \\
\hline Private Security & 15000 & 175000 \\
\hline Contract Cleaning & 10000 & 65000 \\
\hline Civil Engineering & 1500 & 147913 \\
\hline Learnerships & n/a & 86205 \\
\hline Wholesale and retail & 65000 & 979608 \\
\hline Taxi & n/a & 130000 \\
\hline Children in performance activities & n/a & 12000 \\
\hline TOTAL & 1006500 & 3445726 \\
\hline
\end{tabular}

It is not known how many employees are covered by ministerial determinations. ${ }^{41}$ The ministerial determinations are as follows:

- Small business

- Special Public Works Programmes

- Welfare sector

The 2002 amendment to the BCEA converted 16 of the 'old' wage determinations, still in force in terms of the BCEA's transitional arrangements, to sectoral determinations. It is not known how many employers and employees these determinations cover. ${ }^{42}$ It is so long since any of these determinations was updated that it is almost certain that in every case the wage levels in the determinations are way below the current market rates. However, where the determinations do have an impact is that they provide variations on the BCEA. For example, many of these determinations define a 'casual' employee as someone who works

\footnotetext{
41 The DoL could not provide this data.

42 The DoL could not provide this data.
} 
for three days or less per week. Such workers are usually excluded from the coverage of certain provisions in the determination. The 'old' sectoral determinations are as follows:

- Metal containers

- Cement products

- Glass and glassware

- Road passenger

- Hotel trade

- Catering trade

- Meat and cold storage

- Unskilled labour

- Sweets

- Funeral undertaking

- Goods transportation

- Laundry and dry cleaning

- Stone crushing

- Business equipment

- Letting of flats and rooms

- Accommodation establishments

It is evident from the list that some of the determinations are probably wholly or in large part redundant because they have been superseded by bargaining councils. 


\subsection{Enforcement of, and Compliance with the BCEA and Sectoral Determinations}

The Department of Labour employs 706 inspectors to monitor and if need be enforce compliance with the provisions of the BCEA, as well as other labour legislation: 42 are in Mpumalanga, 69 in Limpopo, 159 in Gauteng (49 in Gauteng North and 110 in Gauteng South), 58 in the Free State, 133 in KwaZulu-Natal, 33 in the Northern Cape, 53 in the North West, 95 in the Western Cape, and 64 in the Eastern Cape.

According to the Department, the 706 inspectors did a total of 184070 inspections in the period April to December 2004. Extrapolating from this data would give a total of 245000 inspections per year, with each inspector doing on average about 347 inspections per year. ${ }^{43}$ The Department maintains data regarding the sectors in which inspections were conducted. The largest number is in an 'other' category headed 'households, extraterritorial organisations and other', presumably referring mainly to the domestic sector. The next highest number is in the category 'community, social and personal services'. Manufacturing has the next highest total followed by the wholesale and retail trade.

A total of 2008 compliance orders were issued by the inspectors during 2003 and 2241 in 2004. The Department was not able to provide data regarding the number of objections to the above orders that were lodged by employers, but in 2004 the Director-General brought 447 applications to have compliance orders made an order of the Labour Court. The Department maintains that during 2004 it achieved a compliance level of 79 per cent of cases within 60 days of their being reported.

\subsection{Exemptions (or Variations on Application) from the BCEA}

In terms of section 50(1) of the BCEA, any employer may apply for a determination by the Minister to replace or exclude any basic condition of employment provided for in the BCEA, in respect of any category of employee. The Employment Conditions Commission has determined guidelines in terms of which such applications will be considered by the Department. These guidelines have not been published. The Department nevertheless argues that they are in the 'public domain', and that the Department publicises the fact that employers may apply for such a determination on its web-site and from time to time in the media. 
Applications may be on a BCEA 6 form or in writing, providing the information stipulated in the BCEA 6 form. This in essence requires full particulars of the variation sought, including the number of employees affected thereby, and a motivation as to why the application should be granted. Importantly, an employer making such an application is required to annex the consent of all registered unions that represent the employees in respect of whom the determination is to apply. Alternatively, the employer must provide proof that such unions have been notified of the application, and reasonable steps have been taken to bring the application to the notice of employees. Where no agreement can be reached regarding an application, the employer is required to specify the 'points of dissension.'

Both the employer's motivation and the concerns expressed by unions and/or employees are considered in deciding whether to approve an application, as well as any impact there might be on the health and safety of employees, or the family and responsibilities of employees, as a consequence. What the Department refers to as the 'quid pro quo' is also an important consideration. This seems to refer to any concession in respect of other conditions of employment that the employer might be prepared to make, in an endeavour to make the proposed determination more palatable to the employees.

According to the Department, applications are generally finalised within thirty days, during which period of time the applicant may be called upon to provide further information, or an 'in loco' investigation may take place. However, this was not borne out by the figure the Department provided. During 2002/2003 there were 721 such applications received, of which only 181 ( 25 per cent) were granted, 524 (72 per cent) were not finalized, and 3 refused. In the 2003/2004 period 1801 applications were received, of which 297 (16 per cent) were granted, 1464 (81 per cent) were not finalized, and 8 were refused. ${ }^{44}$ According to the Department the large number of pending applications in both years related to exemptions from the Agriculture Sectoral Determination. Because so many applications were received and were relatively complex, the Department appointed an economist to investigate all of them. This led to the long delay in finalising the applications.

A far higher proportion of applications was finalised in the most recent 2004/2005 period. Of 848 applications, 394 were granted (46 per cent) and 228 (26 per cent) were refused. However there were still 31 applications that had not been finalised, as well as a further 193 applications not accounted for. If one excludes the applications not finalised and those not accounted for, the success rate for 2004/2005 was 63 per cent. 
The Department says reasons are given in writing when applications are refused. These reasons generally refer to a failure to comply with the requirements of form BCEA 6, or to the guidelines for determinations referred to above. In terms of these guidelines, certain kinds of determinations can only be granted for a specified period, and others are on an indefinite basis. However as a rule first applications are granted only for twelve months, after which applicants have to reapply.

The successful applications during the 2004/2005 period were in respect of 33 sections of the BCEA, of which by far the highest proportion were applications for exemption from the overtime provisions of the BCEA (34 per cent). The next largest category of applications granted was in respect of the weekly and daily rest periods (14 per cent), followed by annual leave (8 per cent) and family responsibility leave ( 7 per cent).

The Department also provided data regarding applications for exemption from three sectoral determinations. In the case of the determination for the Agriculture Sector (Sectoral Determination 8) there were 1151 applications received of which 767 (67 per cent) were granted. The vast majority of the applications were in respect of wages, but a significant number of applications were also in respect of restrictions on deductions from wages (15 per cent). There were two applications granted in respect of the wages prescribed in the retail sector determination (Sectoral Determination 9) and also two in respect of the private security sector (Sectoral Determination 6). 


\section{Part D: Conclusions}

\section{Bargaining Councils}

Bargaining councils are diverse institutions and one should be cautious about making generalisations about them. While all councils use the same legislative framework, from which they derive certain common features, the enabling nature of the framework gives latitude to the parties to develop councils in different ways. We have sought to aggregate data to provide an overview of the entire system as well as capture some of the diversity in the system by splitting councils into three different categories (i.e. large national and other large councils, regional and small national councils, and small regional and local councils).

Bargaining councils cover just less than a third of employees that are potentially covered by collective bargaining and less than 5 per cent of all such employees are covered by extended agreements. The latter is a tiny proportion of the labour market and it is difficult to understand why this issue has attracted so much controversy. Even in the sectors in which the number of employees covered by extended agreements is relatively high, i.e. Manufacturing and Transport, the proportion of employees is below 16 per cent.

The above does not mean that councils do not create problems for small and new businesses. A shortcoming of the Act in this regard is that the two quantitative requirements for the extension of agreements don't put pressure on employer parties to organise small firms. An employers' organisation with a minority of large employers can meet the first requirement (i.e. employees of party employers as a proportion of all employees). A third measure - party employers as a proportion of all employers - would put pressure on employers' organisations to put effort into recruiting and retaining small firms as members. It is not surprising that in the absence of the third measure that party employers make up only 41 per cent of all registered employers, while the system as a whole is comfortably representative on the first and second measures. National councils and other large councils are even less representative on the third measure than the system as a whole.

However, the measurement of representivity is a problematic exercise. DoL officials state that they measure representivity with respect to all employees within the jurisdiction of the council and not just employees at registered firms. But accurate data is not available on the total number of employers and employees that fall within the sectors and regions covered by councils. This raises a question about using representivity as the basis for extending agreements. The research shows that levels of non-registration constitute a major problem for some councils (although the data needs to be treated with caution). 
Importantly, the research shows that the bargaining council system mainly covers small firms. Even the average size of party firms is not very big. However, the average size of party firms at most of the large national councils is significantly bigger than the average size of non-party firms as well as being much bigger than the average size of party firms at the smaller councils. This suggests that the tensions around bargaining councils and small firms concern mainly the big councils.

Data from the DoL shows that at 11 of 27 councils more than 40 per cent of small firms were members of the party employers' organisations. This is a surprising finding. However, almost all of the 11 councils are relatively small local or regional councils. The finding suggests that the issue might therefore not be so much the numerical representivity of small firms on councils but how effective representation is. Some of the interviews with bargaining council officials confirmed this point, although the interviews also pointed to a way in which tensions had been defused, namely through blanket exemptions.

The research also found that generally bargaining councils did not have a great deal of enforcement capacity. Furthermore, the ratio of agents to employees at the large national councils tends to be much larger than the ratio at the regional and local councils. The smaller local and regional councils also conducted more inspections per agent than the larger national councils and tended to spend considerably more time tracking down unregistered firms. On the other hand, the large national councils issued far more compliance orders, which increased sharply over the period. The findings suggest that non-compliance and non-registration is greater at large councils than at smaller councils.

The number of exemption applications received by councils showed a significant rise between 2000 and 2004, with the success rate (exemptions granted in full, partially granted and subject to conditions) above 70 per cent over the period. The largest proportion of exemption applications came from small firms: in 2002 and 2004 about two-thirds of all applications were from small firms. And the refusal rate for exemption applications from small firms was lower than for all firms and was declining. When splitting the applications into party and non-party applicants one finds that the vast majority of applications came from non-party firms. However, the refusal rate for applications from non-parties is somewhat higher than the refusal rate from all firms.

The research therefore indicates that the exemption system at bargaining councils is no longer the issue it once was. Representivity of councils, however, remains a critical issue, particularly in the light of low representation of employers and problems in measuring representivity. But even if numerical representivity was to improve, the challenge of getting 
effective representation for small firms appears to be intractable. Enforcement is clearly not a solution to this problem.

\subsection{Bargaining Councils: A System in Crisis?}

Although the number of employees covered by councils has increased over the last decade (even if one counts only the coverage of the private sector councils), the number of bargaining councils has declined dramatically. In 1983 there were 104 councils, in 1992 there were 87 councils, in 1995 there were 80 councils, and in 2004 there were 57 councils, of which nine were defunct and/or in the process of being wound up. The decline has not been off-set by the establishment of the five councils in the public sector after the new LRA or by the few other councils that have been established (e.g. Chemical, Fishing, and Wood and Paper). Significantly, the new councils that have been established have in most cases been established with considerable difficulty after a long period of struggle.

Part of the decline in the number of councils is accounted for by the merger of regional and sub-sectoral councils to form bigger national councils (e.g. the Clothing and the Textile councils), but part of the decline is the result of the councils ceasing to function and being de-registered. It could be argued that this is a healthy process, which will end with a smaller number of large national councils covering employees previously covered by regional and local councils. The argument does not seem to be borne out by the evidence. New councils are not established easily and the merger of councils is also a very slow and difficult process (e.g. the merger of regional councils to form a national Clothing council took about eight years and the council is still to all intents and purposes an amalgamation of regional structures rather than a national structure). Where such councils are formed it seems that they generally struggle to maintain a reasonable level of representivity. The problems currently being faced by the Clothing bargaining council are a case in point.

While the slow process of mergers and establishment of new councils is going on, an opposite and more rapid process of decline of regional and local councils is apparent. A number of functioning councils appear to be in a precarious position. If the trend is indeed towards large national councils and the demise of smaller councils, then the likely outcome will be a handful of councils covering only certain sectors, with the vast bulk of the labour market covered by the BCEA or sectoral determinations or plant-level bargaining (with only the latter two setting wages). This raises questions about the future nature of the industrial relations system, particularly given our dearth of knowledge about the extent of plant-level bargaining and what is being negotiated at plant level. 


\subsection{Some Possible Policy Options}

What can be done to address the apparent decline? Firstly, any strategy would have to address the relationship of bargaining councils with small businesses. The data on the average size of firms indicates that the council system primarily covers small businesses, so for the system to survive it has to become more representative of small businesses. There are positive signs. Most of the councils covered in this study appear to have become more sensitive to issues affecting small business and non-parties. At the same time the research identifies a number of areas in which the present bargaining council system could be improved.

Two challenges face bargaining councils with regard to small business. First, the employers' organisations on councils need to become more representative of small businesses in numerical terms. At some councils this has been achieved while at others there is still some way to go. The second challenge is to ensure that representivity in terms of numbers translates into effective representation of small business interests in council negotiations. A third measure of representivity, namely that party employers' organisations need to be representative of all employers in the industry might help in this regard. Such a measure would put pressure on employers' organisations to recruit smaller firms and to better accommodate them in their organisation and in the way they approach negotiations. This should translate into agreements with which small firms can live. However, the threshold for this measure needs not be set at 50 per cent and the Minister would need to take account of the nature of the industry and efforts made by the employer parties to organise small firms. We would also propose that each measure is not viewed on its own; the Minister would need to take account of the levels of all three measures.

With regard to the above proposal, it must be emphasised that any moves to change the system must bear in mind its voluntary nature. Care needs to be taken that any changes do not create incentives for employers to leave employers' organisations, thereby making councils unrepresentative.

Another policy option would be to encourage councils to give consideration to blanket exemptions of particular categories of business, particularly new and small businesses. The phase-in approach adopted by some councils provides a useful example. Blanket exemptions should, however, not be entirely automatic. To qualify, firms should first register with councils. This will assist in monitoring and enforcement. It would not be advisable to introduce a blanket exemption through legislation because only councils know the circumstances of their sectors and the type of businesses that should qualify for such exemptions. 
There are other areas where the bargaining council system can be improved. For example, there does not appear to be any sound justification for councils to have such long lists of criteria or to leave applicants in the dark as to how the criteria are weighted.

However, we believe that more research needs to be done on bargaining councils and small businesses, In particular, research needs to be done that examines empirically in what ways councils have a negative impact on small businesses and, if so, why the exemption system is not dealing with such cases. In this regard, it should also be noted that the DoL has data on bargaining councils that is not accessible to the public. We recommend that efforts are made to publish this data, so that it can inform the debate about bargaining councils, small businesses and the labour market. 


\section{The BCEA and Sectoral Determinations}

It is difficult to understand why bargaining councils have attracted so much controversy compared to sectoral determinations, since far more employees are covered by sectoral determinations than by bargaining councils. And, compared to sectoral determinations, the number of workers covered by extended bargaining councils agreements is small. One explanation might be the limited information one has on the sectoral determinations and BCEA. For example, there is no data on the coverage of ministerial determinations or the wage determinations that were converted to sectoral determinations by the 2002 amendment to the BCEA. It is also unknown what the level of compliance is with the BCEA and sectoral determinations. Arguably there is probably a low level of compliance because of the limited enforcement capacity of the DoL: only 706 inspectors are spread across 10 main offices.

Furthermore, the guidelines used by DoL to assess applications have not been made public or do not enjoy very wide publicity and it is difficult to assess the success rate of applications for variation because of the very high number of applications that were not finalised in 2002/3 and 2003/4.

It is clear that more research needs to be done on the sectoral determinations and BCEA. They cover a very large number of workers and there is only very sparse data on their coverage and enforcement. 


\section{References}

Chamber of Mines/National Union of Mineworkers. 2004. Joint Investigation by the Chamber of Mines and the National Union of Mineworkers in the Various Bargaining Options. Unpublished report compiled by the Chamber of Mines and the National Union of Mineworkers.

Du Toit, D., Bosch D, Woolfrey, D., Godfrey, S., Rossouw, J., Christie, S., Cooper, C., Giles, G. \& Bosch, C. 2003. Labour Relations Law (4 ${ }^{\text {th }}$ edition). LexisNexis Butterworths: Durban.

Elsley, T. 2005. 'Wage Review', in Bargaining Monitor, Vol.21 No.162. Labour Research Service: Cape Town.

Godfrey, S., Theron, J. \& Maree, J. 2004. 'Bargaining Councils and Small Business: Some implications for the establishment of a bargaining council in the mining sector', in an unpublished report entitled Joint Investigation by the Chamber of Mines and the National Union of Mineworkers into the Various Bargaining Options compiled by the Chamber of Mines and the National Union of Mineworkers.

Holtzhausen, M. \& Mischke, C. 2004. 'Bargaining Councils in other sectors of the South African Economy', in an unpublished report entitled Joint Investigation by the Chamber of Mines and the National Union of Mineworkers into the Various Bargaining Options compiled by the Chamber of Mines and the National Union of Mineworkers.

Labour Research Service. 2005. The LRS Report: Bargaining Indicators 2005, Vol.10. Labour Research Service: Cape Town.

Theron J. 2001. Bargaining Councils and Dispute Resolution. Unpublished report submitted to the Department of Labour and the Commission for Conciliation, Mediation and Arbitration. 


\section{Annexure A}

List of bargaining councils to which questionnaires were sent. The councils that completed and returned questionnaire are marked with an asterisk.

- Building Industry BC (Bloemfontein)*

- Building Industry BC (Boland)

- Building Industry BC (Cape)*

- Building Industry BC (Kimberley)*

- Building Industry BC (Southern and Eastern Cape) ${ }^{45_{*}}$

- Canvas and Ropeworking Industry (Cape)

- Canvas Industry BC (Witwatersrand and Pretoria)*

- Chemical Industry BC*

- Clothing Industry BC*

- Commercial and Distributive Trade BC (Kimberley) ${ }^{46}$

- Contract Cleaning Industry BC*

- Diamond Cutting Industry BC*

- Electrical Industry BC*

- Entertainment Industry BC*

- Fishing Industry BC

- Furniture Industry BC (Eastern Cape)*

- Furniture Industry BC (Free State)

- Furniture Industry BC (KwaZulu-Natal)*

- Furniture Industry BC (Northern Region)*

- Furniture Industry BC (South Western Districts)*

- Furniture Industry BC (Western Cape)*

- Grain Co-operative BC*

- Hairdressing and Cosmetology Trade BC (Cape)*

- Hairdressing and Cosmetology Trade BC (KwaZulu-Natal)

- Hairdressing and Cosmetology Trade BC (Pretoria)*

- Hairdressing and Cosmetology Trade BC (Semi-National)*

45 The council now administers the Building Industry BC (East London). The data supplied by the Building Industry $\mathrm{BC}$ (Southern and Eastern Cape) incorporated the East London council.

46 The Commercial and Distributive Trade BC (Kimberley) has only recently produced an agreement after a period of about four years without one. The Secretary did not complete a questionnaire because the council was to all intents and purposes not functioning during much of the period covered by the questionnaire. 
- Jewellery BC*

- Laundry and Dry-Cleaning BC (Cape)*

- Laundry and Dry-Cleaning BC (Natal)*

- Leather Industry BC

- Meat Trade BC (Gauteng)*

- Metal and Engineering Industry BC*

- Motor Industry BC

- Motor Ferry Industry BC

- New Tyre Manufacturing BC

- Passenger Transportation Trade BC

- Restaurant and Catering Trade BC

- Road Freight Industry BC*

- SA Road Passenger Industry BC*

- Sugar Industry BC

- Tearoom and Restaurant Trade BC (Pretoria)*

- Textile Industry BC*

It should also be noted that although the National Bargaining Council for the Wood and Paper Sector was not sent a questionnaire because it was registered only in 2005, the council did participate in the research by providing data on its representivity. 